\author{
Federal Reserve Bank of New York \\ Staff Reports
}

\title{
Repo Runs: Evidence from the Tri-Party Repo Market
}

\author{
Adam Copeland \\ Antoine Martin \\ Michael Walker
}

Staff Report No. 506

July 2011

Revised August 2014

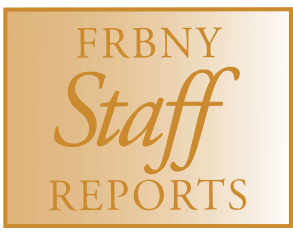

This paper presents preliminary findings and is being distributed to economists and other interested readers solely to stimulate discussion and elicit comments. The views expressed in this paper are those of the authors and do not necessarily reflect the position of the Federal Reserve Bank of New York or the Federal Reserve System. Any errors or omissions are the responsibility of the authors. 


\title{
Repo Runs: Evidence from the Tri-Party Repo Market
}

Adam Copeland, Antoine Martin, and Michael Walker

Federal Reserve Bank of New York Staff Reports, no. 506

July 2011; revised August 2014

JEL classification: E44, E58, G24

\begin{abstract}
The repo market has been viewed as a potential source of financial instability since the 2007-09 financial crisis, owing in part to findings that margins increased sharply in a segment of this market. This paper provides evidence suggesting that no system-wide run on repo occurred. Using confidential data on tri-party repo, a major segment of this market, we show that the level of margins and the amount of funding were surprisingly stable for most borrowers during the crisis. However, we also document a sharp decline in the tri-party repo funding of Lehman in September 2008.
\end{abstract}

Key words: tri-party repo, wholesale funding, money markets, short-term funding

Copeland, Martin: Federal Reserve Bank of New York (e-mail: adam.copeland @ ny.frb.org, antoine.martin@ny.frb.org). Walker: University of California, Berkeley (e-mail:

mwwalker@econ.berkeley.edu). The authors thank Viral Acharya, Brian Begalle, Michele Braun, Lucinda Brickler, Richard Crump, Dan Dehlinger, Darrell Duffie, Michael Fleming, Ken

Garbade, Gary Gorton, Anil Kashyap, Jamie McAndrews, Susan McLaughlin, Steve Pesek, Andy Sturm, and members of the Task Force on Tri-Party Repo Infrastructure for helpful comments on an earlier draft. They would also like to thank an anonymous referee and associate editor for their helpful suggestions. All remaining errors remain with the authors. Walker gratefully acknowledges financial support through a National Science Foundation Graduate Research Fellowship (Grant No. DGE 1106400). The views expressed in this paper are those of the authors and do not necessarily reflect the position of the Federal Reserve Bank of New York or the Federal Reserve System. 
Repurchase agreements, or repos, have been at the center of policy discussions since the financial crisis of 2007 to 2009. In particular, Gorton and Metrick (2012) document a large increase in margins in one segment of the repo market, which they interpret as a run. Because of this finding and the repo market's role as a major source of short-term funding, repo markets have been viewed as an important source of financial fragility. In this paper we show that, based on evidence from the tri-party repo market, which is a major segment of the repo market, there was no system-wide run on repo.

A repo is the sale of an asset, coupled with the promise to repurchase the asset at a specific price at a specific future date. Repos are similar to collateralized loans, aside from their special treatment in case of bankruptcy (see Appendix C in Copeland, Martin, and Walker (2010) for more detail). The market value of the securities purchased typically exceeds the value of the cash the borrower receives. This difference, which is normally expressed as a percentage, is called the "margin" and measures the extent to which the cash loan is overcollateralized 1

The repo market is an important financial market because it is a key source of short-term funding for securities dealers and some of their clients. 2 This market is also critical for secondary market liquidity in Treasuries and other securities, and plays an important role in the pricing and price discovery of cash and derivatives instruments.

The U.S. repo market comprises several segments. As we describe in detail in Section I, it is useful to distinguish the bilateral market, where the settlement of the repo is handled by the trading parties, from the tri-party repo market, where a third party provides settlement and collateral management services. These two segments behaved very differently during the crisis.

Gorton and Metrick (2012) study data from a high-quality dealer trading with other highquality dealers in the bilateral repo market. They show that margins increased dramatically, similar to the "margin spirals" modeled in Brunnermeier and Pederson (2009) (see also Adrian

\footnotetext{
${ }^{1}$ The margin is equal to the ratio of the value of collateral posted over the amount of cash lent minus one. An alternative measure is called the "haircut," which is equal to one minus the ratio of the cash lent over the value of the collateral posted.

${ }^{2}$ We use the terms "securities dealers" and "dealers" interchangeably.
} 
and Shin (2010)). Looking at data from another segment of the bilateral market, in which dealers lend to their clients (notably hedge funds), we find similar increases in margins. Hence, it appears that the bilateral repo market suffered from a tightening of financing conditions. In the tri-party repo market, however, margins for all but the lowest-quality collateral changed very little, as shown in Figure 1.

We discuss this figure in more detail later in the paper, but note here that margins for repos collateralized by U.S. Treasuries and agency debentures did not change throughout the crisis. Furthermore, margins for repos backed by the lowest-quality collateral used in the tri-party repo market, labeled "nongovernment," increased by only two percentage points, from 5\% to $7 \%$. This increase is much less pronounced than in the bilateral market we study. Figure 2 shows the differences in the average margin for overnight repos between the segment of the bilateral market for which we have data and the tri-party repo market. These spreads are sizable for corporate bonds (over 10 percentage points in 2009) and enormous for private-label collateralized mortgage obligations and asset-backed securities (over 30 percentage points in 2009).

Krishnamurthy, Nagel, and Orlov (forthcoming) also study the tri-party repo market, using data collected from SEC filings of money market mutual funds and securities lenders, two types of investors with a large presence in tri-party repo. Consistent with our paper, their study shows that margins appear mostly stable in the tri-party repo market. They report, however, that money market mutual funds stopped accepting private asset-backed securities (ABS) as collateral in the tri-party repo market during the recent financial crisis. We show a decline in the use of ABS as collateral, but, unlike Krishnamurthy, Nagel, and Orlov (forthcoming), we find that ABS were accepted as collateral throughout the recent financial crisis. These two results may be consistent, however, because our data contain a larger set of investors. Hence, it may be the case that while money market mutual funds stopped accepting ABS, other cash investors were willing to accept ABS as collateral during the recent financial crisis.

The different behavior of margins across the tri-party and bilateral repo markets is puzzling, 


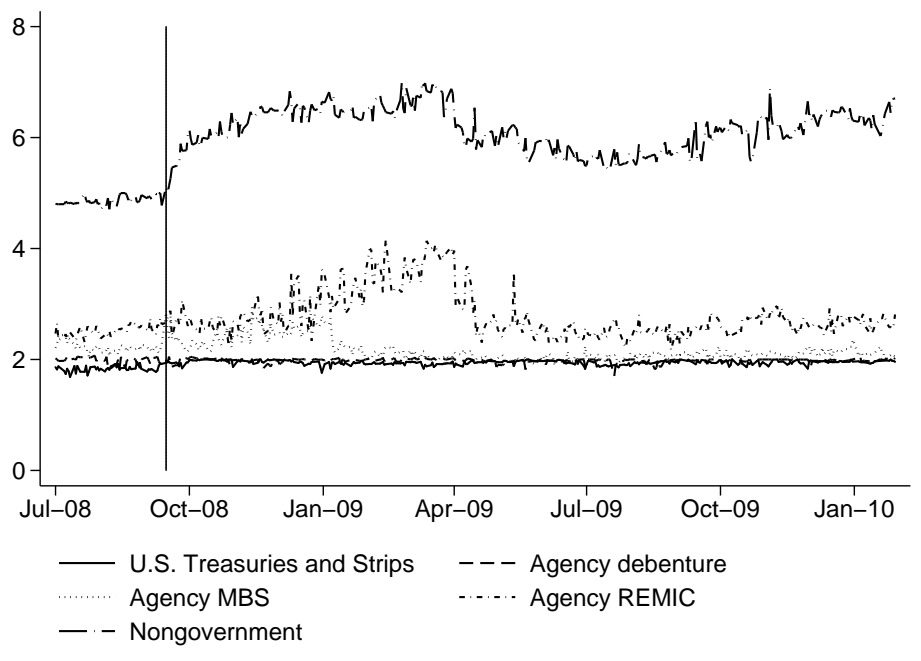

Figure 1. Median margins in tri-party repo by asset class. This figure presents the daily time-series of the median margin by asset class in tri-party repo. Margin is equal to the ratio of the value of collateral posted over the amount of cash lent minus one and is reported as a percent. The vertical line denotes the date of Lehman Brothers' bankruptcy filing. MBS is mortgage-backed securities and REMIC is real estate mortgage investment conduits. Nongovernment securities are those not backed by the full faith and credit of the federal government. Examples are equities, corporate bonds, and other securities not issued by the U.S. Treasury or other government agencies.

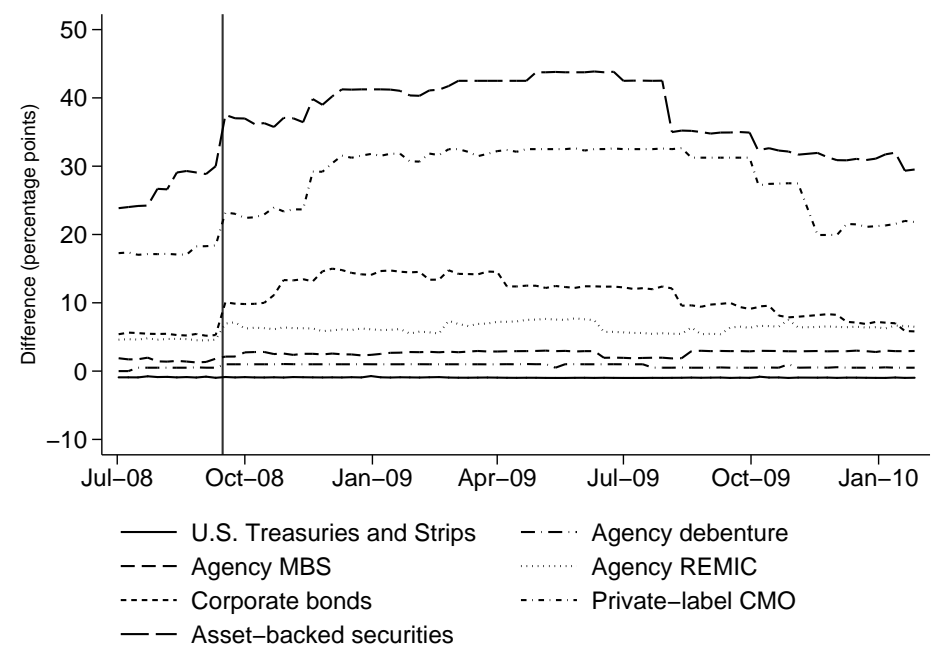

Figure 2. Differences in median margins in tri-party repo by asset type. This figure presents the daily time-series of the difference in median margins for an asset class across the bilateral and tri-party repo markets. Differences in median margins are calculated as the bilateral repo margin median minus the tri-party repo margin median for each asset class. The vertical black line corresponds to Lehman Brothers' bankruptcy. MBS is mortgage-backed securities, REMIC is real estate mortgage investment conduits, and CMO is collateralized mortgage obligations. 
because these markets are similar along several important dimensions. The contractual details of the repurchase agreements are similar in both markets, and a large subset of similar collateral is posted in both markets. Market participants note that both markets are used by financial firms for funding purposes. Further, large securities dealers often lend cash in the bilateral repo markets and then use the securities obtained in those bilateral repo transactions as collateral in tri-party repo transactions (i.e., dealers rehypothecate the collateral they receive in the bilateral repo market). Consequently, it is noteworthy that margins, an important feature of any repo contract, behaved so differently across these similar and connected markets.

While we do not observe a significant tightening of funding conditions in the tri-party repo market, we document a large and precipitous decline in the tri-party repo book of Lehman Brothers in the days preceding the bankruptcy of its holding company. This evidence suggests that when facing a crisis, a dealer should not expect to see higher margins in the tri-party repo market. Rather, a dealer's cash investors are more likely to simply pull their funding.

The different uses of margins across these two repo markets may have implications for financial stability, so it is important for academics and policy makers to understand them. Indeed, while increases in margins can be problematic, as argued in Gorton and Metrick (2012), they can also play an equilibrating role, as studied in Martin, Skeie, and von Thadden (forthcoming). When faced with increasing counterparty risk, investors can respond to the risk in two ways: they can stop lending, or they can increase the margins associated with the repo transaction. A borrower is likely better off losing some funding through higher margins than losing funding altogether as a result of investors pulling back (as may have been the case for Lehman). Hence, our results highlight potentially different run dynamics between the bilateral and the tri-party repo markets. Understanding whether investors will increase margins or deny funding abruptly could be important to the stability of securities dealers and financial markets, as well as for developing effective policy responses.

Understanding the different use of margins is also important in the policy debate on minimum margin requirements. In a speech in April 2012, Vítor Constâncio, Vice President of the 
ECB, noted that "Recent analytical studies (largely based on empirical studies on U.S. markets) have highlighted that margin requirements and haircuts in repo markets are procyclical. To counter this effect, it has been proposed that minimum haircuts could be applied permanently as a means of limiting system leverage or used temporarily in response to overheated market conditions as a macro-prudential tool.:3 Our finding that margins in some important segments of the repo market are not procyclical weaken this rationale somewhat.

To build a foundation of knowledge upon which to understand this paper's results, in Section I we provide institutional background on the U.S. repo market with a focus on the tri-party repo segment. We then present the main empirical findings of the paper in Section II, followed by a discussion of the results and their policy implications in Section III. Finally, we conclude in Section IV.

\section{Institutional Background}

The U.S. repo market consists of several segments, as shown in Figure 3.4 Securities dealers are at the center of our figure and operate in all five repo market segments. In segments 2 and 3, securities dealers borrow cash from investors. Segment 5 is the opposite: securities dealers provide funding to clients or other firms. It is common for dealers to reuse the securities they have received as collateral in segment 5 as collateral for their own borrowing in segments 2 or 3, a practice known as rehypothecation. Finally, securities dealers also redistribute securities and cash among themselves. This is done either in a bilateral market (segment 4) or in the General Collateral Finance repo (GCF Repo ${ }^{\circledR}$ ) market (segment 1), a blind brokered market primarily for Treasury and agency securities (see Fleming and Garbade (2003) for more details about GCF Repo).

Segments 1 and 2 are both considered tri-party repo because repos traded on these segments

\footnotetext{
${ }^{3}$ See https://www.ecb.int/press/key/date/2012/html/sp120427.en.html.

${ }^{4}$ See Adrian et al. (forthcoming) for more detail about the data sources for various repo market segments and Copeland et al. (2012) for more institutional details about and related policy issues in the tri-party repo market.
} 


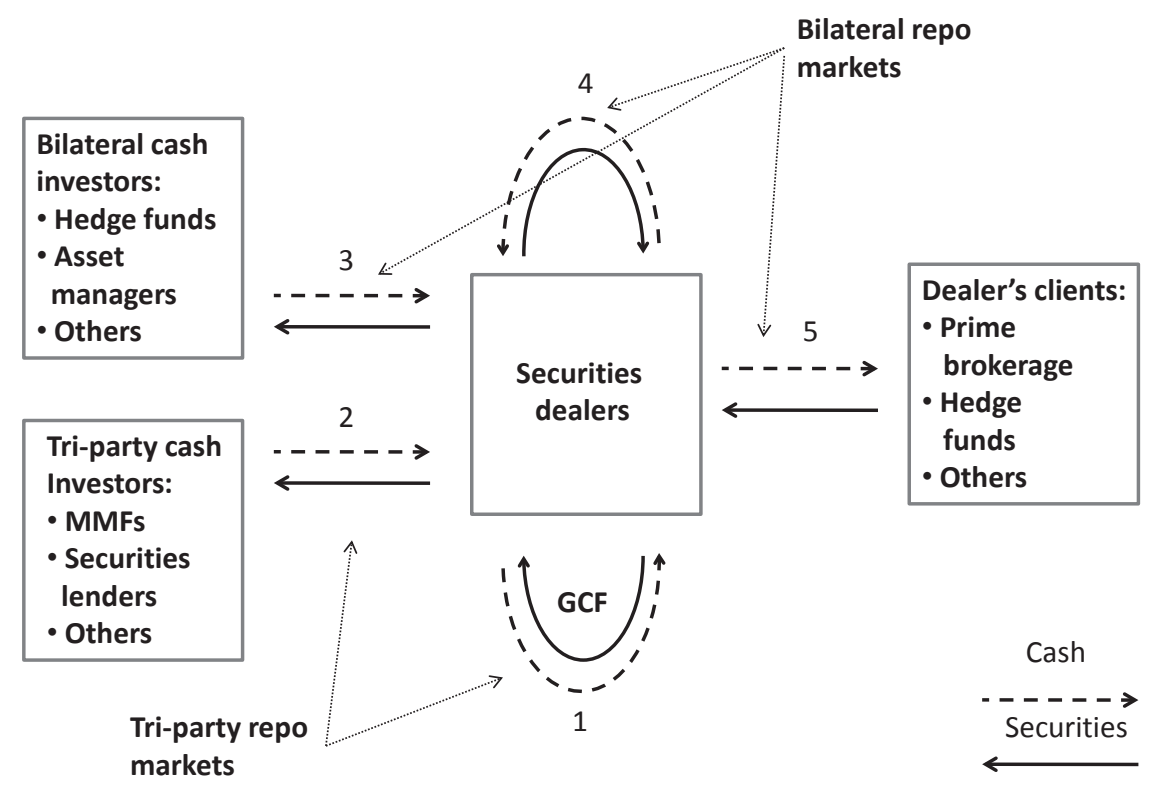

Figure 3. Stylized map of the U.S. repo market. This figure presents a map of the various U.S. repo markets. MMF is money market mutual funds and GCF is the General Collateral Finance Repo Service operated by the Fixed Income Clearing Corporation. This figure was taken from a post co-written by this paper's authors on the Liberty Street Economics site (see the blog post on June 25, 2012). 
are settled on the books of clearing banks, which are the third party to the transaction (the role of the clearing banks is described more fully in the following subsection). In contrast, in the bilateral repo segments, cash investors and collateral providers settle the transaction themselves. Another important difference is that the tri-party repo market is used to finance general collateral, which means that cash investors are willing to accept any security within a class of securities. Bilateral repos, on the other hand, sometimes allow for general collateral and sometimes impose narrow restrictions on the securities eligible for collateral. Dealers choose to transact in tri-party and bilateral repos for different reasons. Our conversations with market participants suggest that tri-party repo is considered more cost-efficient, while bilateral is preferred when parties want to interact directly with each other or if specific collateral is requested.

Lack of data makes it impossible to estimate the size of each segment of the market separately. Nevertheless, we can provide some sense of the size of the market by estimating the total value, from the securities dealers' point of view, of repos (delivering securities for cash) and reverse repos (delivering cash for securities) outstanding on a typical day (see Appendix A for more details). For the July to August 2008 period, we estimate that the sum of all repos outstanding on a typical day-segments 2 and 3, as well as the repo side of segments 1 and 4 -represented approximately $\$ 6.1$ trillion. About $40 \%$ of this activity is tri-party repo, while the remaining $60 \%$ is bilateral repos. The sum of all reverse repos outstanding - segment 5, as well as the reverse repo side of segments 1 and 4 -is about $\$ 4$ trillion, most of which (about $92 \%$ ) comprises bilateral reverse repos. Note that it may not be appropriate to add the total repo and reverse repo numbers to arrive at a measure of the size of the whole market because of double-counting. Indeed, every repo in the interdealer market is also a reverse repo, and we do not know the size of the bilateral interdealer market.

Figure 3 is also useful for placing this paper in context with the segments of the repo market studied by others. Gorton and Metrick (2012) use margin data from a dealer operating in the bilateral interdealer repo market (segment 4). The bilateral data we study in this paper 
are from dealers lending to their clients (segment 5). Our paper focuses on the tri-party repo market and, more specifically, on segment 2. This is also the segment of the market studied in Krishnamurthy, Nagel, and Orlov (forthcoming), who have data on the investments of money market mutual funds and securities lenders. We are not aware of any data source that covers segment 3 explicitly.

\section{A. Main Actors in Tri-Party Repo}

We now focus our attention on the tri-party portion of the repo market. There are three main actors operating in this segment: collateral providers (or dealers), cash investors, and clearing banks. We discuss each of these in turn.

Securities dealers are the main cash borrowers in this market. Primary dealers, those securities dealers that can trade directly with the Federal Reserve, account for most of the activity. Other dealers, some large hedge funds, and other institutions with large portfolios of securities also participate in the tri-party repo market, but they represent a small share of the total volume.

Dealers enter the tri-party repo market for at least two reasons. First, they seek to finance the securities they hold in their role as market makers. Rather than use their own capital, they prefer to borrow cash using the securities as collateral (Tuckman (2010)). In this way dealers can obtain considerable leverage and finance large portfolios of securities using very little capital 5

Second, dealers provide intermediation services to clients seeking cash-for example, in their role as prime brokers to hedge funds. A dealer may lend cash to a client through a bilateral

\footnotetext{
${ }^{5}$ Consider the stylized example of a dealer with $\$ 1$ billion in capital. This dealer can use its capital to buy $\$ 1$ billion in securities and then repo these securities to obtain cash. If the margin on the repo is $5 \%$, the dealer can get $\$ 950$ million in cash. With this cash, the dealer can buy new securities and repo them out to get more cash. Assuming the same margin, the dealer can get an additional $\$ 902.5$ million in cash in that way. Continuing this process, the dealer can obtain a portfolio of securities worth $\$ 20$ billion with its $\$ 1$ billion in capital. The formula to find the value of the portfolio of securities is $1+0.95+0.95^{2}+\ldots=\sum_{i=0}^{\infty} 0.95^{i}=\frac{1}{1-0.95}=20$. This example provides an upper bound, because it assumes that the dealer is fully leveraged, which is not generally the case.
} 
repo transaction (see segment 5 in Figure 3). The interest rate on the repo will typically be lower if the client allows the dealer to rehypothecate the assets that serve as collateral. If allowed, the dealer could use the client's assets as collateral to obtain cash in the tri-party repo market. In effect, then, the dealer serves as an intermediary between cash lenders in the tri-party repo market and prime broker clients in the bilateral repo market.

The second set of actors consists of cash investors, which are more numerous and diverse than the set of collateral providers. In our data set, investors are listed as a single firm but can include the securities lending division of a bank as well as the asset management division. Similarly, a money market mutual fund complex is considered a single investor. Extensive discussions with market participants suggest that money market mutual funds represented between a quarter and a third of the cash invested in the tri-party repo market during the crisis, while securities lenders represented another quarter. More recent detailed investor data provided by the clearing banks are broadly consistent (see the Liberty Street Economics blog post on July 17, 2013).

Securities lenders are a significant presence because they are looking for a safe way to reinvest the cash received as collateral when they lend securities. (In the U.S., most securities lending is done against cash collateral.) Hence, securities lenders usually have large pools of cash that they seek to reinvest on behalf of their clients. Investment strategies for these pools of cash often resemble the investment strategies of money market mutual funds 6 Not surprisingly, then, a substantial portion of the cash obtained from securities lending activity is reinvested in tri-party repo 7

According to Federal Reserve Bank of New York (2010), the top 10 dealers finance about $85 \%$ of the value of tri-party repo securities, while around $65 \%$ of the cash invested in tri-party

\footnotetext{
${ }^{6}$ This is due partly to the fact that many securities lending deals are "open," meaning that the lenders must return the cash collateral to the borrower as soon as that borrower returns the security. Hence, the securities lender is exposed to "redemption requests" that are somewhat similar to the liquidity demands faced by money market mutual funds.

${ }^{7}$ Keane (2013) provides a current overview of securities lending, as well as the risks inherent with reinvesting cash obtained from lending securities.
} 
repo is provided by the top 10 cash investors. Each day, the largest individual dealers regularly finance more than $\$ 100$ billion in securities each day. The largest cash investors individually provide daily tri-party repo financing in excess of $\$ 100$ billion.

The third set of actors is the clearing banks: JPMorgan Chase and the Bank of New York Mellon. The clearing banks play several important roles as providers of clearing and settlement services. They take custody of securities used as collateral in a tri-party repo transaction, they value the securities and ensure that the specified margin is applied, they settle the transaction on their books, and they offer services to help dealers manage the use of their collateral. The tri-party repo clearing banks do not match dealers with cash investors, nor do they play the role of brokers in that market.

The clearing banks act as an agent to the collateral providers and the cash investors in all the roles noted above. In the U.S. tri-party repo market, the clearing banks also play the role of principal because they finance the collateral provider's securities during the day 8 We describe the timing that leads to this extension of credit in Appendix B and detail the role this can play in exacerbating fragilities in the discussion section.

\section{B. Empirical Description}

The Federal Reserve Bank of New York collects data on the tri-party repo market. The data are daily and include the quantity and type of collateral posted in this market as well as the margins associated with various types of collateral. These data do not include the universe of dealers, but rather all the major players. Together these major players account for more than three-quarters of total tri-party repo activity. For each dealer, an observation is the daily total value of collateral posted and the amount of posted collateral associated with the margin by collateral class. For example, dealer X posted $\$ 102$ billion of agency mortgage-backed

\footnotetext{
${ }^{8}$ One goal of the the Task Force on Tri-Party Repo Infrastructure is to sharply reduce the amount of intraday credit extended by the clearing banks in this market (TPR Task Force (2010)). Copeland et al. (2012) discuss this aspect of the U.S. tri-party repo market in more detail. The reforms are ongoing and expected to achieve their goal of reducing the clearing banks' extension of credit to $10 \%$ of the notional value of the market by the end of 2014 (see http://www.newyorkfed.org/banking/tpr_infr_reform.html for more detail).
} 
securities (MBS) on January 1, 2009 as collateral, and \$2 billion of that collateral is for the margin requirements. Hence, we can deduce that dealer $\mathrm{X}$ borrowed $\$ 100$ billion in cash, securing that loan with $\$ 102$ billion in agency MBS 9 We can then calculate the average margin for each dealer for each asset class for each date.

For investors, the data are in two different forms. For one clearing bank, denoted clearing bank A, we know the joint distribution of collateral and investors for the major investors in tri-party repo. For each investor, we observe the daily total value of collateral accepted by asset class, including the margin and excluding accrued interest. For example, we observe that investor A was allocated $\$ 10$ billion of Treasuries, $\$ 5$ billion of agency MBS, and $\$ 5$ billion of corporate bonds on a specific day. For the other clearing bank, denoted clearing bank B, we know the joint distribution of investors and dealers. For each dealer, we observe the daily total amount of cash lent by all of its investors. For example, dealer $\mathrm{X}$ borrowed $\$ 15, \$ 10$, and $\$ 5$ billion from investors $\mathrm{A}, \mathrm{B}$, and $\mathrm{C}$, respectively, on a specific day. Both the investor and the dealer data are at a daily frequency, from July 1, 2008 to January 27, 2010 10

Over this time period there were 32 dealers active in our sample, a large number of which were primary dealers. Even within our sample of the larger dealers in tri-party repo, the dealer side of the market is quite concentrated, with the top five dealers accounting for $57 \%$ of collateral posted and the top 10 accounting for $86 \%$. We separate dealers into two categories: "large" dealers with a daily average of more than $\$ 50$ billion in posted collateral, and "small" dealers with a daily average of less than $\$ 50$ billion. On average, large dealers provide about $\$ 140$ billion of collateral each day, using 11 different types of collateral, while small dealers

\footnotetext{
${ }^{9}$ The collateral valuations include accrued interest, so our calculations of cash borrowed will be overstated by the amount of accrued interest. However, this is a tiny amount, especially because we are considering a period of very low interest rates.

${ }^{10}$ Recall that GCF Repo trades settle in the tri-party repo market. Depending on the question, including GCF Repos along with regular tri-party repos could be considered double-counting. In the investor data, we observe GCF Repos and so can remove these observations when appropriate. In the dealer data, however, we do not observe a breakdown between GCF Repo and regular tri-party repo trades. Starting after our data end, the TriParty Repo Infrastructure Reform Task Force publishes snapshots of the tri-party repo market, including statistics on the nominal value of GCF repos (see http://www.newyorkfed.org/banking/tpr_infr_reform.html). In May 2011, the total amount of securities delivered to the FICC for GCF repos was \$171.6 billion.
} 
provide $\$ 10$ billion using six types of collateral.

Large dealers tend to borrow from a number of investors. Using the investor data from clearing bank B, we find that the top five dealers of that clearing bank borrow from an average of 53 investors each. Yet dealers still rely significantly on specific investors: for the top five dealers, the largest investor's share of a dealer's overall borrowing is 19\%. Not surprisingly, small dealers borrow from fewer investors. The median number of investors for the five dealers who borrow the smallest amounts is one. It should be noted that the composition and characteristics of dealers differ across clearing banks, so that the behavior of dealers of clearing bank B may not entirely generalize to that of clearing bank A.

Like the dealer side, there is concentration on the investor side, with roughly $70 \%$ of collateral posted held by the 10 largest investors in our data. The 10 largest investors typically lend over $\$ 100$ billion each day across a number of dealers 11 From our data on clearing bank $\mathrm{B}$, the largest number of dealers to which an investor lent cash on a single day was 11 . Small investors, which make up the majority of the investors in our data but account for only a small fraction of the cash lent, generally lend to a single dealer on a given day. The value-weighted median number of dealers to which an investor will lend cash on a single day is six. The statistics on the number of dealers to which an investor will lend are understated, however, because they are based on data from one clearing bank and the larger cash investors are active with both clearing banks.

Our data begin after the fall of Bear Stearns but before Lehman Brothers' bankruptcy. Before Lehman declared bankruptcy, almost \$2.5 trillion worth of collateral was posted in the tri-party repo market each day. This number is down slightly from a historic high of $\$ 2.8$ trillion in April 2008 (Federal Reserve Bank of New York (2010)). After Lehman Brothers declared bankruptcy, collateral posted in this market fell gradually until about July 2009, after which the amount of collateral posted in the tri-party repo market stabilized at a level slightly

\footnotetext{
${ }^{11}$ To compute these numbers, we combined investors' positions across clearing banks. This entailed adding dollars of collateral held (from clearing bank A) and dollars of cash invested (from clearing bank B). Because of margins, these figures are not equivalent, but for these purposes this difference is not important.
} 
above $\$ 1.5$ trillion (see Figure 4). This decline is also seen in the amount of collateral posted after margins are taken out and thus is not a product of margins changing over time. We believe the decline in collateral posted in tri-party repo reflects a number of outside processes, rather than problems with the tri-party repo market itself. These processes include (i) a general deleveraging by dealers in response to the financial crisis; (ii) runoff caused by maturing assets and a decline in new issuance; (iii) declines in valuations that reduced the size of dealers' portfolios; and (iv) the removal of agency MBS securities through the Federal Reserve's LargeScale Asset Purchase program 12 Given that the quantity of collateral posted in the tri-party repo market stabilized during the summer of 2009, we divide our sample into two periods. We denote July 2008 to June 2009 as the "crisis" period and July 2009 to January 2010 as the "stable" period.

Across these two periods, the composition of collateral posted in tri-party repo did not change substantially (see Table I). We categorize all the securities used as collateral in the tri-party repo market into two groups: government and nongovernment securities. We define government securities to be those that are backed by the full faith and credit of the federal government. Government securities include Treasury securities, debentures issued by Fannie Mae, Freddie Mac, and Ginnie Mae, and agency MBS. Nongovernment securities, then, are those issued by private entities and/or those entities that do not have federal government backing. Examples are equities, corporate bonds, and commercial paper.

Across the stable and crisis periods, the share of government securities remains stable at $82 \%$. For the most part, the stability in shares across periods holds even when disaggregating to the collateral class level. Hence, broadly speaking, the portfolio of securities used as collateral within the tri-party repo market has been quite stable.

However, our definition of stable and crisis periods does obscure a substantial decline in nongovernment securities at the beginning of our sample. As seen in Figure 4, there was

\footnotetext{
${ }^{12}$ In November 2008 the Federal Reserve announced it would purchase up to $\$ 600$ billion in housing agency debt and agency MBS. Then, in March 2009, the Federal Reserve decided to expand its purchases of agencyrelated securities and longer-term Treasury securities, with total asset purchases of up to $\$ 1.75$ trillion. More details can be found at http://www.newyorkfed.org/markets/funding_archive/lsap.html.
} 


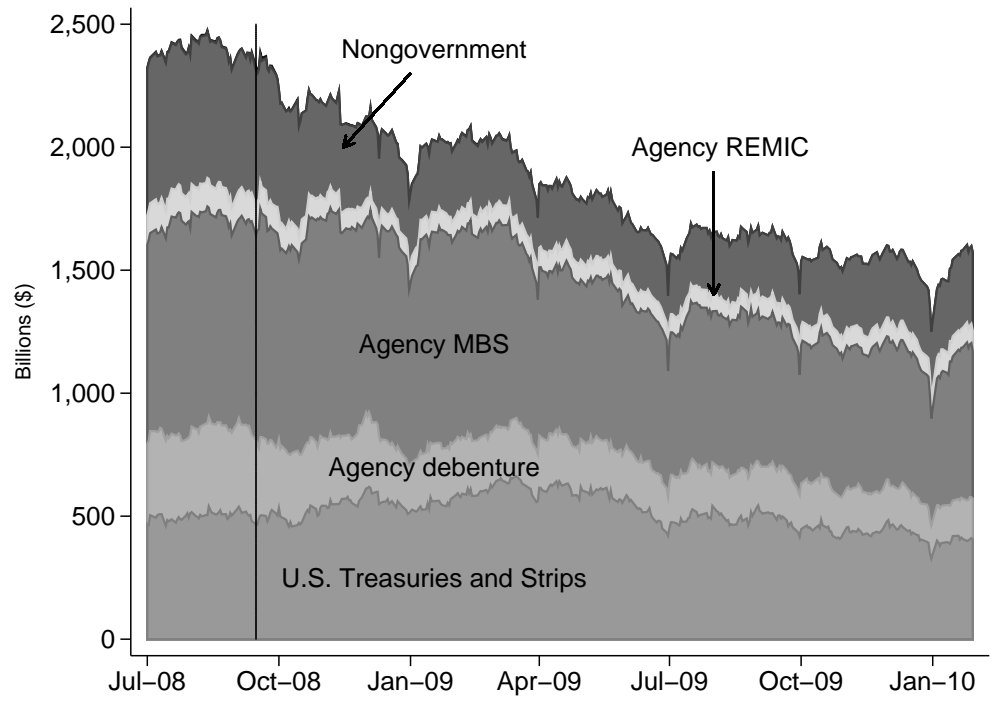

Figure 4. Tri-party repo market size. This figure describes the composition of collateral posted in tri-party repo over time. The vertical line represents Lehman Brothers' bankruptcy. MBS is mortgage-backed securities and REMIC is real estate mortgage investment conduit. Nongovernment securities are those not backed by the full faith and credit of the federal government. Examples are equities, corporate bonds, and other securities not issued by the U.S. Treasury or other federal government agencies. 


\section{Table I}

\section{Composition of Tri-Party Repo Collateral}

This table presents the composition of securities posted as collateral in tri-party repo as a percent of the total, over the entire sample as well as two sample periods. "Crisis" is the period from July 2008 to July 2009, "Stable" is from July 2009 to January 2010, and "All" covers both sample periods. MBS is mortgage-backed securities and REMIC is real estate mortgage investment conduits. Government securities are those backed by the full faith and credit of the federal government.

\begin{tabular}{llccc}
\hline & & Crisis & Stable & All \\
\hline \multirow{3}{*}{ Government } & Agency Debentures & 12.6 & 11.4 & 12.2 \\
& Agency MBS & 38.3 & 37.5 & 38.0 \\
& Agency REMIC & 4.3 & 4.8 & 4.5 \\
& U.S. Treasuries and Strips & 26.8 & 29.0 & 27.4 \\
& subtotal & 82.1 & 82.7 & 82.2 \\
\hline \multirow{5}{*}{ Nongovernment } & Asset-Backed Securities & 2.2 & 2.4 & 2.2 \\
Collateral & Commercial Paper & 0.4 & 0.3 & 0.4 \\
& Corporate Bonds & 5.5 & 5.9 & 5.6 \\
& Equities & 4.1 & 4.0 & 4.1 \\
& Money Market & 1.3 & 1.6 & 1.4 \\
& Municipal Bonds & 0.9 & 0.7 & 0.9 \\
& Other & \\
& Private-Label CMO & 0.2 & 0.4 & 0.3 \\
& Whole Loans & 2.7 & 2.0 & 2.5 \\
& subtotal & 0.7 & 0.1 & 0.5 \\
& & 18.0 & 17.5 & 17.9 \\
\hline
\end{tabular}

${ }^{a}$ The "Other" collateral class is a residual category and so the composition of its collateral changes over time. 
about $\$ 600$ billion in nongovernment collateral in July and August of 2008. Starting around September 2008 (the same month Lehman Brothers declared bankruptcy), the amount of nongovernment collateral posted in tri-party repo fell steadily until the first quarter of 2009, when it leveled out at around $\$ 300$ billion.

Two of the larger collateral classes within the nongovernment category are ABS (also known as private or non-agency ABS) and corporate bonds. Krishnamurthy, Nagel, and Orlov (forthcoming) report that money market mutual funds, which conduct almost all of their repo transactions in tri-party repo, stopped accepting private ABS as collateral in their repo dealings with securities dealers during the second half of 2008 and the beginning of 2009. They also report a dramatic decline in the acceptance of corporate bonds as collateral over this same period. Our data are consistent with the findings of Krishnamurthy, Nagel, and Orlov (forthcoming) in that we observe a substantial decline in the use of ABS and corporate bonds as collateral in the tri-party repo market during the financial crisis (see Figure 5). From July 2008 to April 2009, the value of ABS collateral used in the tri-party repo market declined by $66 \%$ (from about $\$ 75$ billion to about $\$ 25$ billion). For corporate bonds, the decline over the same period is about $\$ 80$ billion, or roughly $44 \%$. Our findings differ from those of Krishnamurthy, Nagel, and Orlov (forthcoming), however, in that we observe the continued use of ABS as collateral in the tri-party repo market during the financial crisis. These two sets of findings can be reconciled, however, by noting that our data cover all types of investors, not just money market mutual funds 13 Hence, combining our results with those from Krishnamurthy, Nagel, and Orlov (forthcoming) suggests that while money market mutual funds refused to accept ABS as collateral during the height of the crisis, this was not true for other types of cash investors.

\footnotetext{
${ }^{13}$ Because our investor data are aggregated up to the investor complex (e.g., Vanguard), we cannot break out the type of collateral held by money market mutual funds versus other types of investors.
} 


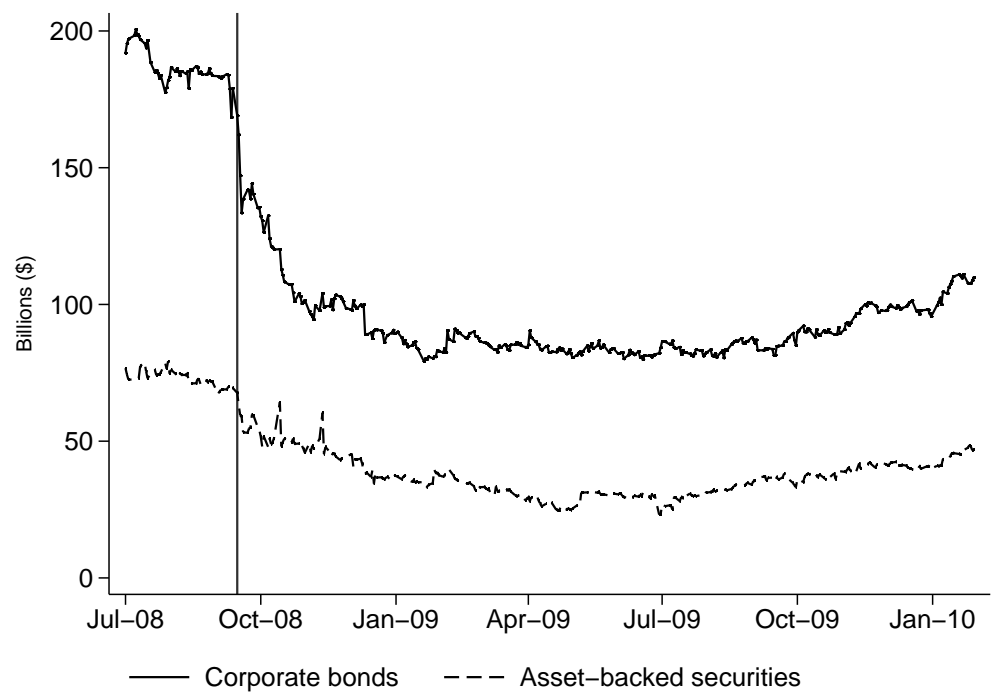

Figure 5. Use of corporate bonds and asset-backed securities as collateral in the tri-party repo market. This figure presents daily time-series of the total value of corporate bonds and asset-backed securities used as collateral in tri-party repo. The vertical line represents Lehman Brothers' bankruptcy.

\section{Main Empirical Findings}

In this section, we analyze margins and the value of collateral posted in our sample to show that, in contrast to the bilateral repo market, the tri-party repo market was surprisingly stable during the crisis. To make this case, we first examine the behavior of tri-party repo margins and compare them to our data on bilateral repo margins. We then analyze the value of collateral posted in this market and document how little investors and dealers alter their repo arrangements on a daily basis, because this could be an alternative way in which investors manage risk. The one exception to the stability of collateral values was Lehman Brothers, so we also discuss the failure of Lehman and explore how changes in counterparty risk affect margins and the total value of collateral posted. 


\section{A. Margins in Tri-Party Repo}

If the dealer defaults on its repo agreement, the collateral securing the transaction partially protects the cash investor from losses. The margin on a repo transaction, which measures how much a repo transaction is overcollateralized, is a way for a cash investor to minimize losses from liquidating collateral in the event of default.

Margins may differ across collateral types for a variety of reasons, including the assets' liquidity, credit risk, and underlying price volatility. We explore these potential differences in Table II, which presents average margins by asset class over the whole sample, as well as during the crisis and stable periods. Based on conversations with market participants, there seems to be agreement on a basic ordering of the "quality" of assets used as tri-party repo collateral (see TPR Task Force (2010, p.18) for an example of this ordering). We order the asset classes in Table II from high to low quality according to this industry metric. We expect to see higher margins associated with lower-quality collateral. Note that the effect of an asset's underlying price volatility on margins is likely dampened by the overnight maturity of most repos in this market 14

Table II confirms that margins differ across collateral type. In general, lower-quality collateral commands higher margins relative to higher-quality collateral. Indeed, securities perceived to be of high quality, such as U.S. Treasuries, agency debentures, and agency MBS, have lower margins relative to those securities perceived to be of lower quality, such as ABS and corporate bonds.

Table II also shows that, as highlighted in the introduction, changes in margins across the stable and crisis periods are very small-the average margin across all collateral types is roughly equal across the two periods (see the last row of Table II). As illustrated in Figure 1, for the three asset groups that make up the majority of collateral posted in this market (i.e.,

\footnotetext{
${ }^{14}$ While we lack maturity information in our data, industry contacts consistently report that the largest tenor in this market is, by far, overnight. For example, Fitch Ratings Fund \& Asset Manager Rating Group reports in its Money Market Funds U.S.A. Special Report (October 4, 2010) that $81.8 \%$ of repo allocations by Fitch-rated taxable money market mutual funds as of August 31,2010, were overnight.
} 


\section{Table II \\ Tri-Party Repo Margins: Mean and Standard Deviation}

This table presents statistics on the margins observed in tri-party repo. Margin corresponds to the amount a repo transaction is overcollateralized and is equal to the ratio of the value of collateral posted over the amount of cash lent minus one (reported as a percent). "Crisis" margins are computed over July 2008 to July 2009, "Stable" margins over July 2009 to January 2010, and "All" margins over the entire sample period; "SD" is standard deviation. Securities are ordered from high to low quality, based on an ordering obtained from conversations with market participants. MBS is mortgage-backed securities, REMIC is real estate mortgage investment conduits, and CMO is collateralized mortgage obligations. Government securities are those backed by the full faith and credit of the federal government.

\begin{tabular}{|c|c|c|c|c|c|c|c|}
\hline & & \multicolumn{2}{|c|}{ Crisis } & \multicolumn{2}{|c|}{ Stable } & \multicolumn{2}{|l|}{ All } \\
\hline & & $\begin{array}{c}\text { Mean } \\
\text { (percent) }\end{array}$ & $\mathrm{SD}$ & $\begin{array}{c}\text { Mean } \\
\text { (percent) }\end{array}$ & $\mathrm{SD}$ & $\begin{array}{c}\text { Mean } \\
\text { (percent) }\end{array}$ & SD \\
\hline & U.S. Treasuries and Strips & 1.7 & 0.59 & 1.8 & 0.42 & 1.7 & 0.54 \\
\hline Government & Agency Debentures & 1.9 & 0.49 & 1.9 & 0.39 & 1.9 & 0.47 \\
\hline \multirow[t]{5}{*}{ Collateral } & Agency MBS & 2.3 & 0.59 & 2.0 & 0.40 & 2.2 & 0.56 \\
\hline & Agency REMIC & 3.1 & 1.31 & 2.6 & 0.59 & 2.9 & 1.15 \\
\hline & Money Market & 3.8 & 1.29 & 4.1 & 1.19 & 3.9 & 1.26 \\
\hline & Commercial Paper & 4.2 & 1.75 & 3.9 & 0.63 & 4.1 & 1.57 \\
\hline & Corporate Bonds & 6.2 & 2.80 & 6.0 & 1.71 & 6.1 & 2.50 \\
\hline Nongovernment & Equities & 6.3 & 1.57 & 8.5 & 2.28 & 7.0 & 2.08 \\
\hline \multirow[t]{5}{*}{ Collateral } & Municipal Bonds & 7.7 & 7.74 & 5.3 & 3.76 & 7.1 & 7.04 \\
\hline & Private-Label CMO & 6.3 & 2.83 & 5.9 & 3.43 & 6.2 & 2.99 \\
\hline & Asset-Backed Securities & 7.1 & 3.90 & 5.8 & 1.73 & 6.7 & 3.40 \\
\hline & Whole Loans & 8.7 & 1.16 & 8.3 & 4.74 & 8.7 & 1.58 \\
\hline & Other $^{a}$ & 4.4 & 6.30 & 3.4 & 1.29 & 3.9 & 4.66 \\
\hline All & & 2.8 & 2.22 & 2.7 & 2.00 & 2.8 & 2.16 \\
\hline
\end{tabular}

$a$ The "Other" collateral class is a residual category and so the composition of its collateral changes over time. Consequently, the statistics on the mean and standard deviation of this collateral class are hard to interpret. Nevertheless, we include these statistics for completeness. 
Treasuries, agency debentures, and agency MBS), margins hardly moved over the second half of 2008. After the Lehman Brothers' bankruptcy, margins for nongovernment collateral did rise, although the increase was only (roughly) from 5\% to $7 \%$.

We further illustrate the lack of adjustment in margins by regressing the level of margins on a set of collateral class and dealer dummies. The goal of this regression is to demonstrate that a substantial amount of the variation in margins is explained using only simple mean effects. Formally, letting $\operatorname{MARGIN}_{d j t}$ denote the average margin of dealer $d$ on collateral $j$ at time $t, D E A L E R_{d j t} \in\{1,2, \ldots, D\}$ denote the dealer's identity, and $\operatorname{COLLTYPE}_{d j t} \in\{1,2, \ldots, J\}$ denote the collateral type, we estimate

$$
\operatorname{MARGIN}_{d j t}=\alpha_{0}+\sum_{k=2}^{D} I_{k=\operatorname{DEALER}_{d j t}} \eta_{k}+\sum_{k=2}^{J} I_{k=\operatorname{COLLTYPE}_{d j t}} \zeta_{k}+\alpha_{1} C_{d t}+\varepsilon_{d j t}
$$

where $I_{x=y}$ is an indicator variable equal to one when $x=y, C_{d t}$ is a dummy variable equal to one if dealer $d$ uses a specific clearing bank at time $t$, and $\varepsilon$ is an error term. We estimate this regression on our sample of 85,246 observations and find that the simple mean effects of dealer and collateral type explain $31 \%$ of the variation in margins, highlighting the remarkable stability of margins over the 2007 to 2009 financial crisis 15

The regression results are also informative as to whether dealers face differences in margins. Krishnamurthy, Nagel, and Orlov (forthcoming) report little variation in margins using data on money market mutual funds and securities lenders. In contrast, our estimated coefficients on the dealer fixed effects reveal substantial heterogeneity. These two sets of results are not necessarily inconsistent, however, because our data encompass a larger set of investors. In Appendix C, we report the estimated coefficients from the regression.

As highlighted in the introduction, the lack of change in margins is very different from the large change in margins documented in Gorton and Metrick (2012). To further explore the

\footnotetext{
${ }^{15}$ Estimating the regression with interaction terms between the dealer and collateral type dummies raises the adjusted $\mathrm{R}^{2}$ to 0.59 . We also estimated the regression with daily time dummies. The estimated coefficients and standard errors changed trivially and the adjusted $\mathrm{R}^{2}$ ticked up from 0.308 to 0.309 .
} 
difference in margin dynamics in tri-party repo versus bilateral repo, we use confidential daily survey data on margins of bilateral repos obtained from the Federal Reserve Bank of New York. In this segment of the repo market (segment 5 in Figure 3), dealers provide liquidity to hedge funds, real estate investment trusts, and banks, for example. These margins reflect what dealers request from customers to which they lend cash through a repo. To some extent, the securities that dealers obtain as collateral in the bilateral repo market are rehypothecated by the dealer and used as collateral in the tri-party repo market. In these cases, the dealer's role is to serve as an intermediary between cash investors in tri-party repo (e.g., money market mutual funds and securities lenders) and a dealer's prime brokerage clients (e.g., hedge funds).

To compare margins in the tri-party and bilateral repo markets, we first need to match asset classes for the collateral used in both markets as best we can. Table III provides descriptions of the collateral classes we are able to match with some degree of confidence, from high to low quality. While the match is not perfect, the collateral classes are roughly similar. 16 The margin data for the bilateral market are associated with repos of overnight maturity. While we do not know the maturity of repos in our tri-party repo data, numerous market participants stated that the overwhelming majority of tri-party repos were overnight during our sample period 17

We graphically present the differences in median margins between the two repo markets, or margin spread, in Figure 2. A positive spread of 10 indicates that the margin is 10 percentage points lower in the tri-party repo market than the bilateral repo market (e.g., margins of $5 \%$ versus $15 \%$ ). As detailed in the figure, the spread between the median margins in the bilateral and tri-party repo markets increases with lower-quality collateral. The median margin is higher in the bilateral repo market for all collateral classes except Treasuries. After the Lehman Brothers' bankruptcy, these margin spreads increased, reaching more than 40 percent-

\footnotetext{
${ }^{16}$ Note that, in the case of corporate bonds, we capture only investment grade (IG) bonds for the bilateral market, while this category includes both IG and non-IG bonds for the tri-party repo market. Accordingly the margin spread between the two markets is likely to be understated for that category.

${ }^{17}$ Furthermore, the daily unwind, explained in Appendix B, undercuts the usual idea of maturity in the tri-party repo market. If a securities dealer defaults during the day, when all repos have been unwound, a cash investor in a term repo might choose to not send cash to the securities dealer in return for collateral, even if it was supposed to do so.
} 


\section{Table III \\ Matching of Asset Classes}

This table presents how we match asset classes in the bilateral and tri-party repo data. MBS is mortgage-backed securities, REMIC is real estate mortgage investment conduits, and CMO is collateralized mortgage obligations.

\begin{tabular}{ll}
\hline $\begin{array}{l}\text { Dealers as Cash Providers } \\
\text { (bilateral) }\end{array}$ & $\begin{array}{l}\text { Dealers as Collateral Providers } \\
\text { (tri-party) }\end{array}$ \\
\hline U.S. Treasuries & U.S. Treasuries and Strips \\
Agency Debentures & Agency Debentures \\
Agency MBS & Agency MBS \\
Agency CMO & Agency REMIC \\
High-Grade Corporate Debt & Corporate Bonds \\
Alt-A, Prime MBS & Private-Label CMO \\
Subprime & Asset-Backed Securities \\
\hline
\end{tabular}

age points for subprime collateral. In general, the margin spreads increased during the fall of 2008, peaked sometime in the first half of 2009, and were close to their July 2008 level at the beginning of 2010 .

The different behavior of margins in the bilateral and tri-party repo markets is a puzzle. These two markets are similar, as both use the same contractual form and the same types of collateral. The purpose of some transactions in both markets is similar-market participants have stated that financial entities use both markets for funding purposes. These two markets are also tightly linked; the larger securities dealers operate in both markets and often provide intermediation services by rehypothecating collateral received via bilateral repos into the tri-party repo market. All these connections suggest that margin behavior across these two markets should be similar. In Section III we discuss what we believe is driving the different behavior of margins across these two segments of the repo market.

\section{B. Daily Changes in the Collateral Posted in Tri-Party Repo}

We now turn to the value of collateral posted in the tri-party repo market. Like margins, the size of a tri-party repo transaction is a way for an investor to adjust a trade and potentially 
manage risk. It is possible that investors, while leaving margins constant, change how much they are willing to lend to a dealer if that dealer's credit risk varies. The aggregate data show a steady decline in the total amount of collateral posted in the tri-party repo market from August 2008 to January 2010 (see Figure 4), although it is difficult to pin down what is driving this trend, as discussed in Section I.B. Here we analyze the data at a disaggregated level with the goal of measuring the degree to which investors and dealers adjust the value of their individual trades from day to day, as a way to measure the stability of the market. As detailed below, we find evidence that investors and dealers do not typically adjust the value of their trades from day to day. Rather, these lending relationships are quite stable, a stylized fact that accords with anecdotal evidence from market participants, which consistently characterize dealers as using the tri-party market as a funding source for long-term investments.

To measure the stability of an investor-dealer relationship, we would ideally want data on the amount dealers borrow from investors by collateral type. Because we do not have such data, we examine the dynamics of the relationship between dealers and investors from three perspectives. We start by looking at dealers and the day-to-day percent change in the collateral they post. We then look at investors and the day-to-day percent change in the collateral they accept. Finally, for one clearing bank, we look at the total amount of cash an investor loaned to a dealer over time.

In this analysis, we drop observations involving Lehman Brothers as well as the six quarterend dates in our sample. We drop quarter-end dates because on those days there is usually a large decrease in the amount of collateral posted in the tri-party repo market. Rather than being a meaningful economic phenomenon, the seasonal variation at quarter-end is likely due to balance sheet management by financial institutions that report quarter-end results. Over our sample period, the median percent change in total collateral posted from day to day is $-0.1 \%$, excluding quarter-end dates. On quarter-end dates, the median daily percent change is -6.4 . On the day following quarter-end dates, the total amount of collateral posted rebounds; the median daily percent change is 7.9 (these drops and rebounds can been seen on quarter-end 
dates in Figure 4).

The amount of collateral a dealer posts in the tri-party repo market is extraordinarily stable from day to day, as illustrated by the distribution of the daily percent change in value by collateral type. The median of this distribution is equal to zero; it is not until we look at the tails of the distribution, the 10th and 90th percentiles, that we see substantial percentage changes in the value of collateral posted (see Table IV).

\section{Table IV}

\section{Distribution of the Daily Change in the Value of Collateral Posted by Dealers}

This table presents the percentiles of the distribution of the change in collateral posted by dealer type. An observation is the daily percent change in the total value of collateral posted by a dealer for a given collateral class. Quarter-end dates and all observations on Lehman Brothers are excluded from this analysis. For small and large dealers, there are 30,053 and 51,272 observations, respectively.

\begin{tabular}{cccccc}
\hline Type of & \multicolumn{5}{c}{ Percentiles } \\
\cline { 2 - 6 } Dealer & 10 th & 25th & 50 th & 75th & 90th \\
\hline Small & -24.3 & -2.6 & 0.0 & 1.9 & 18.3 \\
Large & -14.8 & -3.5 & -0.0 & 3.0 & 12.0 \\
\hline
\end{tabular}

A similar point emerges when we look at the investor data. Following the analysis above, for each investor we compute the daily percentage change in the value of collateral received. Because there is substantial heterogeneity among investors, we report these percentiles conditional on the size of the investor (see Table V). We divide investors into quartiles, based on the total collateral received in tri-party repo over our sample period.

For all four groups of investors, the median percent change in collateral received is equal to zero. Furthermore, the 25 th and 75 th percentiles of this distribution are never above $3 \%$ in absolute value. As we saw with dealers, it is only at the tails of the distribution, the 10th and 90th percentiles, that we see larger changes in collateral accepted from one day to the next.

Overall, these statistics strongly suggest that investors and dealers form stable relationships through which dealers can raise a consistent amount of cash from investors from day to day. Further evidence of this behavior is found by examining the total amount of cash an investor lends to a dealer using data from one of the clearing banks. We compute the distribution of 


\section{Table V \\ Distribution of the Daily Change in the Value of Collateral Received by Investors}

This table presents the percentiles of the distribution of the change in collateral received by investor type. An observation is the daily percent change in the total amount of collateral received by an investor. Quarter-end dates are excluded from this analysis. Investors are categorized into quartiles based on the total amount of collateral they received over the sample period. Quartiles are numbered from low (smallest investors) to high (largest investors). From the first to fourth quartiles, the number of observations is $12,335,14,673,13,175$, and 12,442, respectively.

\begin{tabular}{cccccc}
\hline Investor Size & \multicolumn{5}{c}{ Percentiles } \\
\cline { 2 - 6 } (quartiles) & 10th & 25th & 50 th & 75th & 90th \\
\hline 1 & -5.1 & -0.0 & 0.0 & 0.0 & 4.0 \\
2 & -26.5 & -2.8 & 0.0 & 2.1 & 20.0 \\
3 & -15.7 & -2.3 & 0.0 & 1.8 & 13.0 \\
4 & -10.2 & -2.5 & 0.0 & 2.2 & 8.9 \\
\hline
\end{tabular}

the daily change in total cash loaned from an investor to a dealer and find that the median percentage change is zero, and the 25 th and 75 th percentiles are -0.1 and zero, respectively.

The above results, combined with the overnight tenor of most trades and the lack of movement in margins, imply that dealers generally rolled over their tri-party repo trades from day to day. To better understand this behavior, especially for cases in which a dealer is under stress, in the next section we further examine changes in margins and collateral posted in response to changes in dealers' credit ratings.

\section{Dealer Stress and Changes in Margins and Collateral Posted}

So far, we document a lack of movement in margins and collateral posted in tri-party repo throughout the sample period, even during times of crisis. The one exception to this characterization is Lehman Brothers, which experienced a sharp decline in the collateral it posted to tri-party repo in the days leading up to the holding company's bankruptcy filing on September 15, 2008. To better understand how margins and collateral posted change when the dealer is stressed, we begin by detailing the movements of margins and collateral posted in the days leading up to Lehman's bankruptcy. We then use a reduced-form approach to describe 
how margins and collateral posted change alongside changes in market expectations of default for a broader set of dealers.

We start by looking at the dynamics in margins and collateral posted for Lehman Brothers around the date of its bankruptcy. We compute the percentage-point difference between the average margin Lehman faced and the average margin faced by other large dealers. We label this difference "margin spread" and find, somewhat surprisingly, that the average margin faced by Lehman Brothers was no different from those of other large dealers up until the day it declared bankruptcy (see the first row in Table VI). Even the Friday before Lehman declared bankruptcy (September 12), the average margin Lehman faced was a little more than one percentage point greater than those faced by other large dealers. We should reemphasize that margins for these other large dealers were flat over this time period. Recall that Figure 1 shows that the (small) increases in margins in this market occurred after Lehman Brothers declared bankruptcy.

Table VI

\section{Lehman's Last Days}

This table presents statistics describing Lehman's tri-party repo position leading up to its bankruptcy. "Margin Spread" is the difference in percentage points between the average margin Lehman faced minus the average margin faced by a group of other large dealers. "Share of Nongovernment" is the percent of total collateral posted that is classified as nongovernment. Nongovernment securities are those not backed by the full faith and credit of the federal government. Examples are equities, corporate bonds, and other securities not issued by the U.S. Treasury or other government agencies. "Investors" are the total number of Lehman's investors in the tri-party repo market. The numbers for July and August are the average over those months.

\begin{tabular}{lcccccccccccc}
\hline & July & August & \multicolumn{10}{c}{ September } \\
\cline { 3 - 12 } & & & 2 & 3 & 4 & 5 & 8 & 9 & 10 & 11 & 12 & 15 \\
\hline $\begin{array}{l}\text { Margin } \\
\text { Spread }\end{array}$ & -0.05 & -0.13 & -0.08 & -0.07 & -0.10 & -0.03 & 0.03 & -0.03 & 0.48 & 0.66 & 1.11 & 4.11 \\
\hline $\begin{array}{l}\text { Share of Non- } \\
\text { government }\end{array}$ & 25 & 28 & 31 & 31 & 31 & 31 & 31 & 32 & 31 & 32 & 39 & 70 \\
\hline Investors & 70 & 69 & 68 & 68 & 69 & 69 & 69 & 63 & 50 & 48 & 41 & 16 \\
\hline
\end{tabular}

Even the small increases in the margin spread in the last days before Lehman's bankruptcy 


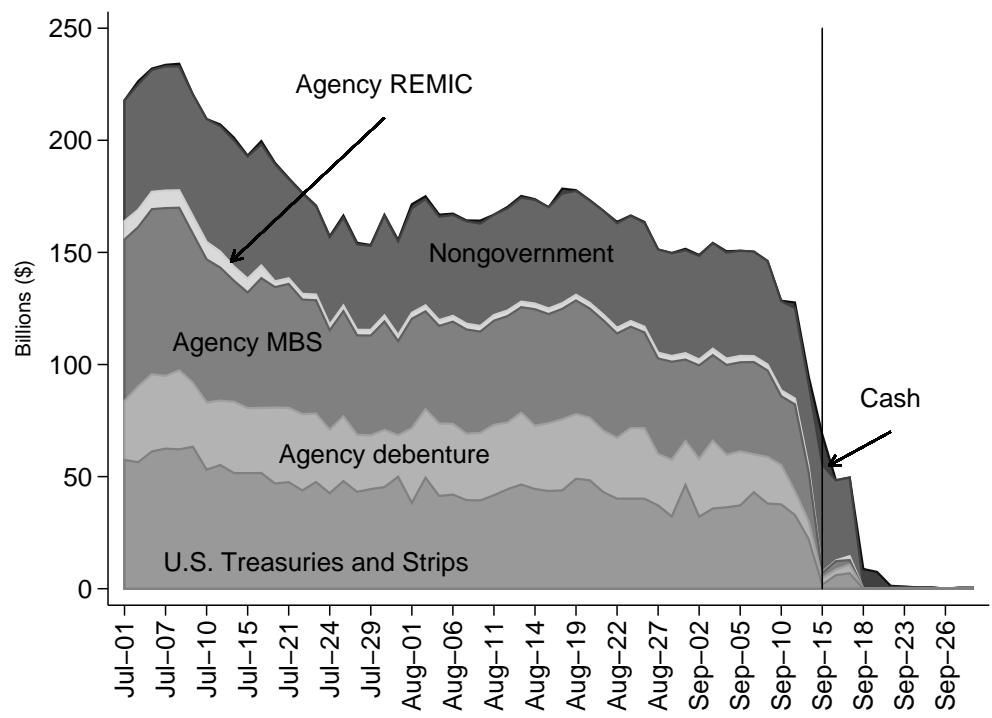

Figure 6. Collateral posted by Lehman Brothers in tri-party repo. This figure presents the composition of collateral posted in tri-party repo by Lehman leading up to its bankruptcy. The vertical line represents Lehman Brothers' bankruptcy. MBS is mortgage-backed securities and REMIC is real estate mortgage investment conduits. Nongovernment securities are those not backed by the full faith and credit of the federal government. Although they rarely exercise it, dealers have the option to post cash as collateral in tri-party repo. 
are mostly explained by a change in Lehman's tri-party repo book toward lower-quality collateral. As shown in the second row of Table VI, from July and August to September, Lehman actually increased the share of nongovernment collateral it posted in tri-party repo. Indeed, the 0.5 percentage point increase in the margin spread from September 11 to 12 coincides with a seven percentage point increase in the share of nongovernment (i.e., lower-quality) collateral.

While Lehman's margins remained roughly flat, there was a collapse in the amount of collateral the firm posted in tri-party repo (see Figure 6). Significantly, the collapse in collateral was not at all gradual, but rather concentrated in the week before the firm declared bankruptcy. From September 9 to 10, the value of collateral Lehman posted shrank by $12 \%$, followed by a large contraction of $26 \%$ from September 11 to 12 . Not surprisingly, alongside these large declines in the value of collateral posted were significant drops in the number of cash investors lending to Lehman (see the third row of Table VI).

The Valukas Report, the court examiner's report looking into the causes of the Lehman bankruptcy, cites sources describing much of the decline in collateral posted by Lehman in tri-party repo as part of a self-imposed trend, although there were additional declines that may have been unplanned (Valukas (2010)). We can think of five reasons for the decrease in collateral posted by Lehman Brothers in the tri-party repo market. First, investors in this market may have pulled back funding to protect themselves against the increased risk of a Lehman Brothers' default. The Valukas Report notes that Fidelity, a large tri-party repo investor, "requested back" its overnight tri-party repo deals on September 12 (Valukas (2010)). Hence, Lehman Brothers may have been forced to finance its securities in other markets (e.g., the GCF Repo market described in Section I) or not at all. Second, Lehman Brothers was forced to post additional collateral with counterparties for other types of transactions over this time, which may have reduced its tri-party repo portfolio. Third, in reaction to rumors of Lehman Brothers' upcoming demise, hedge funds and other Lehman clients were moving their business to other dealers and thus withdrawing their collateral from Lehman Brothers. As described in Duffie (2011), losing clients has an impact on a dealer's balance sheet. In particular, if its clients 
pulled their assets, then Lehman could no longer use these securities as collateral in tri-party repo. Fourth, the wind-down or deleveraging of the short-dated (primarily overnight) matched books in Treasuries, agency debt, and agency MBS likely played a part in the decline of triparty funding in the last few days before the bankruptcy. A similar deleveraging in other asset classes may also have played a role, albeit to a lesser extent. Fifth, and finally, in facing a run by investors, Lehman Brothers may have been selling collateral to raise money.

The case of Lehman Brothers suggests that, when facing a crisis, a dealer should not expect to face higher margins when seeking funding in the tri-party repo market. Rather, cash investors are more likely to simply pull their funding. Given that repos in the tri-party market during this time were mainly overnight, cash investors were able to decrease their lending to Lehman at a rapid pace. Consistent with the idea that investors may care more about the counterparty than the collateral, we observe a decrease in all collateral types. The rising share of nongovernment collateral posted by Lehman could be due to the fact that government assets are easier to sell if a firm needs to raise cash.

We reinforce these findings with regression analysis using information on dealers' credit default swaps (CDS). We obtain daily CDS spread data from Markit, a financial information services firm. To get CDS data on the largest set of dealers over our sample period, we use spreads of five-year modified restructuring U.S. dollar-denominated CDS contracts. This is one of the more liquid CDS contracts traded and, as a result, CDS spreads data are available on a daily basis for 14 dealers in the tri-party repo market over our sample period of July 1, 2008 to January 27, 2010. These 14 dealers include the largest dealers (in terms of collateral posted in this market) as well as a mix of small and medium-sized dealers.

Our goal is to measure the extent to which changes in margins and the value of collateral posted can be explained by changes in the market's perception of a dealer's riskiness, as measured by CDS. Specifically, we regress both margins and value of collateral posted by dealers on their CDS spreads, with dealer, collateral type, and daily time fixed effects. This specification measures how much changes in the CDS (i.e., changes in dealers' default probabilities) 
impact changes in margins or the total value of collateral posted. Let $M A R G I N_{d j t}$ denote the average margin for dealer $d$ on collateral $j$ at time $t$, and denote the credit default spread on dealer $d$ at time $t$ as $C D S_{d t}$. We estimate

$$
\begin{aligned}
\log \left(\text { MARGIN }_{d j t}\right)= & \alpha_{0}+\alpha_{1} \log \left(\mathrm{CDS}_{d t}\right)+\alpha_{2} \log \left(\mathrm{CDS}_{d t}\right)^{2}+ \\
& \sum_{k=2}^{D} I_{k=\text { DEALER }_{d j t}} \eta_{k}+\sum_{k=2}^{J} I_{k=\text { COLLTYPE }_{d j t}} \gamma_{k}+\sum_{k=2}^{T} I_{k=\mathrm{TIME}_{d j t}} \zeta_{k}+\varepsilon_{d j t},
\end{aligned}
$$

where, as previously defined, $I_{x=y}$ is an indicator variable, and DEALER and COLLTYPE identify dealer and collateral type, respectively. Finally, $T I M E_{d j t}$ identifies the day and $\varepsilon_{d j t}$ is an error term. We also run a similar regression replacing the left-hand-side variable with the $\log$ of the dollar value of collateral received.

We first focus on the regression on margins. To allow for the possibility that CDS spreads may have different effects on high- and low-quality collateral, we estimate two regressions: one that includes only government collateral and another that includes only the set of nongovernment collateral. For nongovernment collateral, the estimated coefficient on the log of the CDS spread is statistically insignificant while the coefficient on the log of the CDS squared is economically insignificant. For the government collateral regression, the coefficients on both the $\log$ of the CDS and the log of the CDS squared are statistically significant, but are economically insignificant (see the upper half of Table VII). The estimated coefficients for government collateral imply that a one percentage change in a dealer's CDS is correlated with a 0.003 percentage change in margins, a negligible amount. Hence, while the counterparty can play a role in the level of margins (captured by the dealer fixed effects), changes in counterparty risk, as measured by movements in the CDS spread, have little explanatory power on margins in the tri-party repo market for any collateral class 18

Turning next to the regression of collateral values on CDSs, we find that the estimated coefficients on the log of the CDS spread and the log of the CDS squared are statistically in-

\footnotetext{
${ }^{18}$ To maintain a balanced panel, we did not include Lehman Brothers in the CDS regression analysis. Adding this dealer into the analysis had only negligible effects on the estimated coefficients.
} 


\section{Table VII \\ Estimated Coefficients of CDS Regressions}

This table presents estimated coefficients from regressions that relate CDS spread to margins and, separately, value of collateral posted in tri-party repo. Each regression is estimated including only government collateral and then only nongovernment collateral. Both left-hand-side variables (margins and collateral value) and the CDS spread are in log terms. Not reported are the fixed effect coefficients for collateral class, dealers, and day. Std Err is standard error, clustered by dealer. The government regressions had 18,158 observations and the nongovernment regressions had 20,286. Government securities are those backed by the full faith and credit of the federal government.

\begin{tabular}{lcccc}
\hline & \multicolumn{2}{c}{ Government Collateral } & \multicolumn{2}{c}{ Nongovernment Collateral } \\
\cline { 2 - 5 } & Estimate & Std Err & Estimate & Std Err \\
\hline Independent variable: Margins & 0.003 & 0.001 & 0.012 & 0.007 \\
CDS Spread & 0.0047 & 0.0015 & 0.023 & 0.00013 \\
CDS Spread Squared x 100 & \multicolumn{2}{c}{0.36} & \multicolumn{2}{c}{0.49} \\
$\mathrm{R}^{2}$ & \multicolumn{2}{c}{0.170} & 0.147 \\
\hline Independent variable: Collateral value & 0.051 & 0.145 & -0.170 & 0.003 \\
CDS Spread & 0.001 & 0.003 & -0.003 & 0.52 \\
CDS Spread Squared & \multicolumn{2}{c}{0.81} & \multicolumn{2}{c}{} \\
$\mathrm{R}^{2}$ & \multicolumn{3}{c}{0.0} \\
\hline
\end{tabular}

significant (see the lower half of Table VII). Similar to our regression results on margins, then, the change in counterparty risk has little to no explanatory power on the change in government or nongovernment collateral posted in the tri-party repo market.

Overall, the CDS regression results reinforce our earlier findings. Despite shocks to dealers in the tri-party repo market, investors do not react to adverse information by changing margins, requesting better collateral, or ratcheting down the amount they lend to dealers. The exception to this finding is, of course, Lehman Brothers. The precipitous fall in the amount of collateral Lehman Brothers posted in tri-party repo, coupled with the regression results above, suggests that adjustments in funding may be highly nonlinear. 


\section{Discussion}

In this section, we first ask which factors contribute to the difference in margin behavior between the tri-party repo market and the bilateral repo market. We next ask how we can characterize runs in different segments of the repo market. Lack of data on most segments of the repo market constrains our ability to provide sharp answers to these questions. However, anecdotal evidence from market participants can supplement the limited data we have and help provide answers. Finally, we discuss the policy implications of our results and the role of the Primary Dealer Credit Facility (PDCF) in stabilizing the repo market.

\section{A. Which Factors Contribute to the Difference in Margin Behavior Between Tri-Party Repo and Bilateral Repo?}

An increase in margins during times of stress is broadly consistent with existing theories of repos or secured funding, such as those of Brunnermeier and Pederson (2009), Geanakoplos (2003), and Dang, Gorton, and Holmstrom (2012). Increasing margins is one way secured lenders can protect themselves from the risk of counterparty default. Gorton and Metrick (2012) argue that margins in the bilateral repo market increased when the securities serving as collateral became "informationally sensitive," for example. Higher margins reduce the information sensitivity of the security from the perspective of the cash provider, because they reduce the likelihood that selling the securities will not cover the face value of the repo. This explanation is consistent with the fact that margins in the bilateral market increased more for lower-quality securities, as implied in Figure 2.

Without better data, we are unable to pinpoint more precisely the causes of the increase in margins in the bilateral repo market. For example, it is difficult to know whether the primary driver of the increase was the riskiness of the collateral or the riskiness of the counterparties. However, we can shed some light on a couple of hypotheses.

One hypothesis is that dealers' counterparties, most notably hedge funds and other dealers, 
became more risky during the financial crisis, in which case higher margins would reflect the increased risk taken by dealers when providing cash to their clients or to other dealers through repos. While this possibility could explain the increase in margins in the bilateral repo market we consider, it does not explain why margins increased so much in the interdealer market studied by Gorton and Metrick (2012) compared to the tri-party repo market. Indeed, in both markets, dealers are the borrowers.

Another hypothesis holds that the increase in margins in bilateral repo was due in part to the fact that dealers offering prime brokerage services enjoyed "monopoly rents" at the height of the crisis. According to industry analysts, before the fall of Bear Stearns many hedge funds had only one prime broker. The fall of Bear, a large prime broker, forced a number of hedge funds to look for a new prime broker. In addition, many hedge funds tried to diversify their source of prime brokerage services. However, establishing such relationships can take time and, because of the rush of new demand for services, some prime brokers turned down requests. In this environment, and at the height of the crisis, it is possible that some dealers were able to negotiate very favorable terms (such as high margins) from their prime brokerage clients when lending cash. This explanation, however, would not explain why margins increased in the interdealer market studied by Gorton and Metrick (2012).

A common element across the bilateral repo market we consider and the one studied by Gorton and Metrick (2012) is that dealers are the cash lenders. Dealers are adept at financing and liquidating collateral and thus are likely to be willing to continue lending to a counterparty while taking a higher margin to protect themselves from the risk of default.

In contrast, some of the cash lenders in the tri-party repo market appear reluctant or unprepared to take possession of the collateral. Consequently, these cash lenders prefer to withdraw funding rather than increase margins if they think a dealer is not creditworthy (as noted in Section II.A). For example, SEC rules prevent money market mutual funds from holding outright some of the securities they accept as collateral 19 Withdrawing repo funding was particularly

\footnotetext{
${ }^{19}$ For example, a money market mutual fund may not be able to hold a 30-year Treasury bond, as the remaining maturity of a money market mutual fund's assets must not exceed 13 months.
} 
easy during the crisis because most repos had a term of one business day and so could be canceled unilaterally each day.

Similarly, major categories of tri-party repo investors, such as money market mutual funds and securities lending cash reinvestment pools, have to worry that they may face withdrawal pressures from their own investors. As a result, these tri-party repo investors are very intolerant of credit and liquidity risk. Upon learning that a money market mutual fund in which they have invested is financing a dealer perceived to have creditworthiness issues or a dealer now in default, the fund's investors may preemptively withdraw their funds, regardless of the risk that liquidating the collateral actually represents. This "headline" risk, the risk that a money market mutual fund may find itself in the headline of a news story, is another reason why money market mutual funds may not use margins to manage their risk. Indeed, high margins can do little to mitigate the risk of a run on a money market mutual fund by its own investors.

This last hypothesis, then, is a plausible explanation for the difference in margin behavior across the tri-party and bilateral repo markets. More work, including the gathering of better data across repo market segments, needs to be done to convincingly advance the hypothesis that while dealers, as cash investors in the bilateral repo market, are willing to use margins to mitigate risk, cash investors in the tri-party repo market are not.

With regard to the tri-party repo market, it is worth noting that it is operationally cumbersome to change margins. Margins are not negotiated at the trade level but instead are established in the appendix of legal documents governing the tri-party repo arrangement between a clearing bank and each borrower-lender pair. One reason for this arrangement is that the margins are an input to the collateral allocation tools that the clearing banks put at the disposal of the dealers. Changing margins is possible, of course, but might well require 24 or 48 hours, according to market participants. It is probably more appropriate to think of the fact that changing margins is operationally cumbersome as a symptom of cash investors not using margins as a risk management tool on a day-to-day basis, rather than as a cause of the lack of movement in margins during the crisis. 
The unwind, another key mechanic, also may have affected the margin-setting behavior of cash investors (see Appendix B for more details on the unwind). Because the clearing banks would unwind repos every morning, cash investors were only exposed to the dealers overnight, from approximately 6 p.m. to 8 a.m. the next day. Cash investors may have felt they could always pull away from a troubled dealer before it would have to declare bankruptcy, making the management of margins less important relative to the management of quantities.

\section{B. How Can We Characterize "Runs" in Different Segments of the Repo Mar- ket?}

The behavior of margins in the bilateral repo market can be consistent with a market-wide run, or at least a generalized run on some asset classes, as suggested by Gorton and Metrick (2012). While some of the most risky or illiquid asset classes seem to disappear completely from the market, most asset classes could still be funded, but at much higher margins. In contrast, the tri-party repo market exhibited precipitous reductions in the tri-party repo funding of specific institutions, something more similar to traditional bank runs. In particular, investors did not appear to adjust, in a gradual way, either the margin or the quantity of cash supplied to the market.

Cash investors are able to run on a specific dealer because much of the cash in the triparty repo market is invested overnight. This feature of the market is driven partly by the need of cash investors to respond to their own investors' redemptions. Our data show that while large investors provide a stable amount of funding to the market, this amount occasionally fluctuates sharply, consistent with the need to meet a large redemption. During normal times, these potential needs for cash "withdrawals" are most likely not correlated, so the aggregate supply of funds to dealers remains stable. During a crisis, however, there is the potential for all cash investors to withdraw their funding from one dealer at the same time, something that resembles a traditional bank run. This behavior is similar to the motivation for banking provided by Diamond and Dybvig (1983), who focus on retail bank deposits. 
Of course, given the collateralized nature of repos, cash investors can respond to changes in the perceived riskiness of a dealer by changing the applicable margin. But as this paper documents, cash investors do not seem to use margins to actively manage risk when negotiating

tri-party repos. Consequently, changes to dealer funding are driven mainly by changes in quantities of cash made available. Another way to manage risk could be to gradually reduce funding to a dealer perceived to be in trouble. We see no evidence of such gradual adjustment. During the crisis, most dealers were able to maintain a very stable amount of funding, even during relatively stressful times. The one key exception, of course, is Lehman Brothers, whose tri-party repo book decreased sharply in the days leading up to its bankruptcy.

\section{Some Policy Implications}

Stress in repo markets has attracted considerable attention by policy makers both in the U.S. and around the world. Our paper has implications for at least two important policy questions currently being debated: (i) What policies can reduce financial instability in repo markets? (ii) Should minimum margins be imposed in repo markets?

Since the crisis, the repo market in general, and the tri-party segment in particular, has been viewed as a potential source of financial instability. The Financial Stability Oversight Council notes in its 2012 annual report that the tri-party repo market "remains a significant source of potential contagion" (Financial Stability Oversight Council (2012, p. 133)). The apparent difference in run dynamics observed in the bilateral and tri-party repo markets documented in this paper may have implications for the type of policies that can best maintain financial stability.

First, the absence of margin adjustment is a source of instability in the tri-party repo market. Martin, Skeie and von Thadden (forthcoming) study a theoretical model of repo runs and contrast the case in which margins do not change (as in the tri-party market) with the case in which margins do change (as in the bilateral market). They show that, for some parameter values, runs may occur in the former case but not the latter. Runs do not occur in the latter case 
because investors manage their risk exposures by increasing margins and gradually decreasing the amount of funds lent. The lack of margin adjustment in the former case leads to large and abrupt changes in the amount of funds lent. Consequently, the observation that investors do not adjust margins in times of stress suggests a need for policies to decrease the probability of runs. This could be done, for example, by extending the tenor of repos, thereby reducing the amount of liquidity transformation performed by dealers 20 Liquidity backstops, such as the PDCF (which we discuss in the next section) could also play a role in stabilizing the tri-party market in times of crises, as noted by Dudley (2013).

As noted in the introduction, the analysis of Gorton and Metrick (2012) has often been mentioned as a reason to impose minimum haircuts to reduce procyclicality. The idea is that if margins are constrained to remain at the minimum level during good times, the increase will be less pronounced during times of stress. For example, suppose that, absent regulation, margins for a specific asset class are 5\% in good times but $25 \%$ in times of stress. By setting minimum margins at $15 \%$ for that asset class, a period of stress would entail an increase in margin from $15 \%$ to $25 \%$, rather than from $5 \%$ to $25 \%$.

While our paper does not speak directly to whether minimum margins are desirable, it does suggest that the benefits from minimum margins are unlikely to be the same in different segments of the repo market. In particular, such a policy may have benefits in the bilateral market, where margins appeared to behave procyclically. In contrast, our results show that margins in the tri-party repo market did not behave procyclically, suggesting that the benefit of minimum margins may not be as important.

\footnotetext{
${ }^{20}$ In a July 2012 update on tri-party repo infrastructure reform, the Federal Reserve Bank of New York noted that "dealers are expected to reduce their reliance on short-term tri-party repo financing, particularly for less liquid assets..." (see http://www.newyorkfed.org/newsevents/statements/2012/0718_2012.html).
} 


\section{The Role of the PDCF in Stabilizing the Tri-Party Repo Market}

The PDCF was intended to reduce liquidity concerns in the repo market by serving as a liquidity "backstop," similar to the Federal Reserve's discount window (Adrian, Burke, and McAndrews (2009)). It provided overnight loans to primary dealers, secured by a specified range of eligible collateral. A number of cash investors and dealers have reported anecdotally that the PDCF was an important contributing factor to stabilizing the tri-party repo market. In this section we discuss the ways in which the PDCF may have impacted that market.

We begin by first reporting when dealers accessed the PDCF. The facility was authorized March 16, 2008, the same date JPMorgan initially agreed to buy Bear Stearns, and closed February 1, 2010. Figure 7 shows the weekly average of securities dealers' credit on the Fed's balance sheet. The large spikes in this figure follow JPMorgan's acquisition of Bear Stearns and Lehman Brothers' bankruptcy filing, respectively. Adrian, Burke, and McAndrews (2009) note that "usage [of the PDCF] exploded following the Fed's move to expand PDCF-eligible collateral on September 14 and the bankruptcy of Lehman Brothers Holdings on September 15.

The lack of PDCF use during the week before Lehman's bankruptcy could be due to the fear of stigma21 Valukas (2010) notes that "paradoxically, while the PDCF was created to mitigate the liquidity flight caused by the loss of confidence in an investment bank, use of the PDCF was seen both within Lehman, and possibly by the broader market, as an event that could trigger a loss of confidence. A report by Lehman Brothers Capital Markets Prime Services captured a common critique of the facility: "PDCF borrowing has a considerable stigma in spite of the Fed's efforts to cloak access and guarantee anonymity. Instead, primary dealers view the PDCF as a last resort and will exhaust all other financing sources before pledging collateral here. For this reason, borrowing at this program has evaporated since the [Bear Stearns] merger closed."

\footnotetext{
${ }^{21}$ It is often believed a stigma is associated with borrowing at the Federal Reserve's discount window. See Ennis and Weinberg (2013) for a theory and Armantier et al. (2011) for some empirical evidence.
} 


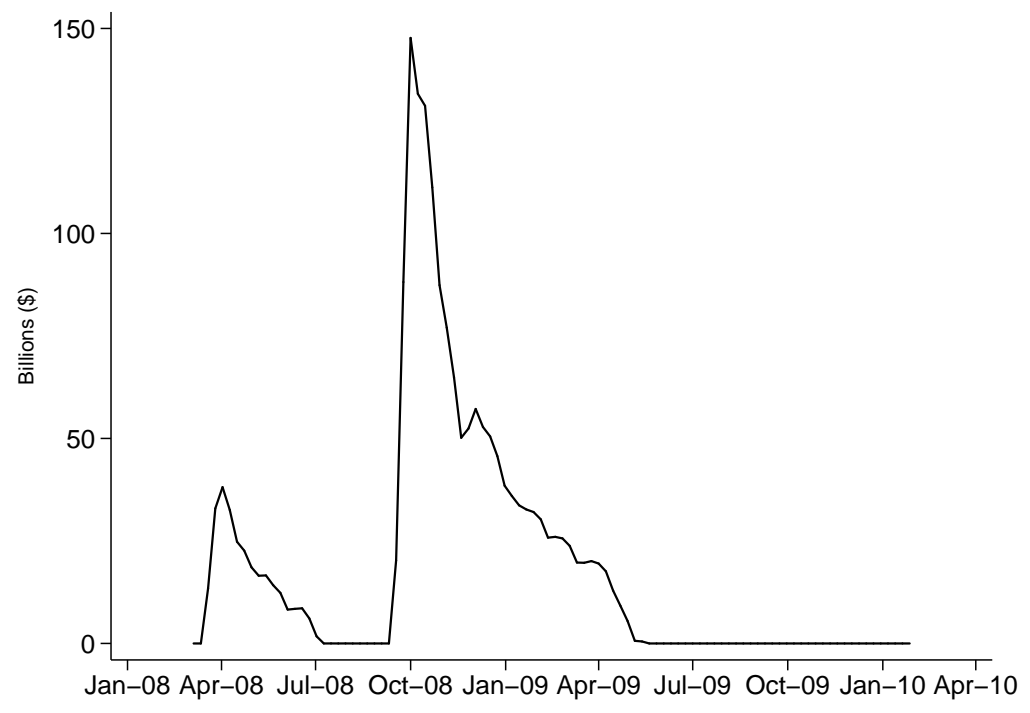

Figure 7. Weekly average of securities dealers' credit. This figure presents a time-series of securities dealers' credit on the Federal Reserve's balance sheet. Source: Federal Reserve H.4.1.

The presence of the PDCF could have stabilized the tri-party repo market in two ways. First, under extreme events the PDCF provided funding to dealers, as shown by the surge in usage of the PDCF following the bankruptcy of Lehman Brothers on September 15. Note that, in this particular case, the stigma associated with the PDCF was likely reduced because multiple dealers were simultaneously accessing the lending facility. Figure 4 shows that the largest declines in tri-party repo funding did not occur until early October 2008, around the same time dealers began cutting back usage of the PDCF. This suggests that the PDCF may have helped dealers smooth their reduction in tri-party repo funding (Krishnamurthy, Nagel, and Orlov (forthcoming) make a similar point).

Second, the presence of the PDCF could have stabilized the tri-party repo market even when the facility was not used. For example, investors may have felt that a particular dealer was unlikely to be troubled unless market conditions deteriorated so much that multiple dealers would be in trouble all at once. In such conditions, the investor would have anticipated that the dealer could most likely access the PDCF without the fear of stigma, because multiple dealers 
would be seeking funding there. Given this insurance, investors may have felt comfortable funding a dealer even when there was considerable uncertainty about market conditions. In this case, then, the PDCF provided insurance against future extreme events.

\section{Conclusion}

Because they have been viewed as a source of financial fragility, U.S. repo markets have been at the center of policy discussions since the financial crisis of 2007 to 2009. This viewpoint has been due, in part, to extrapolation of the work of Gorton and Metrick (2012), who document procyclical margins in a specific segment of the repo market, to the repo market as a whole. In this paper, we show there was no system-wide run on repo based on evidence from a major segment of the market: the tri-party repo market.

Our main findings are that, during the crisis, margins barely moved in the tri-party repo market and funding was very stable for dealers, with one dramatic exception. The behavior of margins contrasts sharply with that in the bilateral market studied by Gorton and Metrick (2012), in which margins increased significantly during the crisis. The differences in behavior across bilateral and tri-party repo markets may have implications for the effectiveness of policies designed to reduce the fragility of U.S. repo markets. While we conjecture as to what may be driving these differences, fully understanding the behavior of securities dealers and investors in repo markets remains an important research topic.

Finally, our paper highlights that the lack of data is a serious limitation for researchers interested in understanding the repo market. In the U.S., the most glaring need is data on the bilateral market 22 There is some hope that better data will eventually be collected. In recommendation 1, the Financial Stability Board's consultative document "Strengthening Oversight and Regulation of Shadow Banking" notes that "authorities should collect more granular data on securities lending and repo exposures amongst large international financial institutions with

\footnotetext{
${ }^{22}$ Adrian et al. (forthcoming) discuss the need for more data on all segments of the market.
} 
high urgency.'23 The report also contains detailed information on the type of data that could enhance transparency in the repo market and would allow researchers to better distinguish between the competing hypotheses discussed in section Section III.

\footnotetext{
${ }^{23}$ See http://www.financialstabilityboard.org/publications/r_121118b.pdf.
} 


\section{REFERENCES}

Adrian, Tobias, Brian Begalle, Adam Copeland, and Antoine Martin, (forthcoming), Repo and securities lending, in M.Brunnermeier and A. Krishnamurthy eds.: Risk Topography: Systemic Risk and Macro Modeling (University of Chicago Press).

Adrian, Tobias, Chris Burke, and James McAndrews, 2009, The Federal Reserve's Primary Dealer Credit Facility, Federal Reserve Bank of New York Current Issues in Economics and Finance, 15, 1-10.

Adrian, Tobias and Hyun Song Shin, 2010, Liquidity and leverage, Journal of Financial Intermediation 19, 418-437.

Armantier, Olivier, Eric Ghysels, Asani Sarkar, and Jeffrey Shrader, 2011, Stigma in financial markets: Evidence from liquidity auctions and discount window borrowing during the crisis, Federal Reserve Bank of New York Staff Report No. 483.

Arora, Navneet, Priyank Gandhi, and Francis Longstaff, 2012, Counterparty credit risk and the credit default swap market, Journal of Financial Economics 103, 280-293.

Brunnermeier, Markus, and Lasse Pedersen, 2009, Market liquidity and funding liquidity, $R e$ view of Financial Studies 22, 2201-2238.

Copeland, Adam, Darrell Duffie, Antoine Martin, and Susan McLaughlin, 2012, Key mechanics of the U.S. tri-party repo market, Federal Reserve Bank of New York Economic Policy Review $18,17-28$.

Copeland, Adam, Antoine Martin, and Michael Walker, 2010, The tri-party repo market before the 2010 reforms, Federal Reserve Bank of New York Staff Report No. 477.

Dang, Tri Vi, Gary Gorton, and Bengt Holmstrom, 2012, Ignorance, debt, and financial crises, Working paper, Yale University. 
Diamond, Douglas, and Philip Dybvig, 1983, Bank runs, deposit insurance, and liquidity, Journal of Political Economy 91, 401-419.

Dudley, William, 2013, Fixing wholesale funding to build a more stable financial system, Remarks at the New York Bankers Associations 2013 Annual Meetings and Economic Forum.

Duffie, Darrell, 2011, How Big Banks Fail and What to Do About It (Princeton University Press).

Ennis, Huberto, and John Weinberg, 2013, Over-the-counter loans, adverse selection and stigma in the interbank market, Review of Economic Dynamics 16, 601-616.

Federal Reserve Bank of New York, 2010, Tri-party repo infrastructure reform, White paper, Federal Reserve Bank of New York, http://www.newyorkfed.org/banking/nyfrb_triparty_whitepaper.pdf.

Financial Stability Oversight Council, 2012, Annual report, Financial Stability Oversight Council, http://www.treasury.gov/initiatives/fsoc/Pages/annual-report.aspx.

Fleming, Michael, and Kenneth Garbade, 2003, The repurchase agreement refined: GCF Repos ${ }^{\circledR}$, Federal Reserve Bank of New York Current Issues in Economics and Finance 9, $1-7$.

Geanakoplos, John, 2003, Liquidity, default, and crashes, endogenous contracts in general equilibrium, in L. P. Hansen, M. Dewatripont, and S. J. Turnovsky, eds.: Advances in Economics and Econometrics: Theory and Applications, Eighth World Conference (Cambridge University Press).

Gorton, Gary, and Andrew Metrick, 2012, Securitized banking and the run on repo, Journal of Financial Economics 104, 425-451.

Keane, Frank, 2013, Securities loans collateralized by cash: Reinvestment risk, run risk, and incentive issues, Federal Reserve Bank of New York Current Issues in Economics and Finance $19,1-8$. 
Krishnamurthy, Arvind, Stefan Nagel, and Dmitry Orlov, (forthcoming), Sizing up repo, Journal of Finance.

Martin, Antoine, David Skeie, and Ernst-Ludwig von Thadden, (forthcoming), Repo runs, Review of Financial Studies.

TPR Task Force, 2010, Task force on tri-party repo infrastructure, Report, Payments Risk Committee, http://www.newyorkfed.org/prc/report_100517.pdf.

Tuckman, Bruce, 2010, Systemic risk and the tri-party repo clearing banks, CFS Policy Paper.

Valukas, Anton, 2010, Report of Anton R. Valukas, Examiner, Report of the Examiner in the Chapter 11 Proceedings of Lehman Brothers Holding Inc. 


\section{Appendix A. Size of the Repo Market}

In this appendix we describe how we estimate the size of the total repo market and its various segments. This approach is based on other work we have done with Eric LeSueur and Isaac Davis (see the Liberty Street Economics blog post on June 25, 2012).

The repo market can be categorized into two groups: (i) tri-party repo and GCF Repo (sections 1 and 2 of Figure 3) and (ii) bilateral repo (sections 3 through 5). Furthermore, from the securities dealers' point of view, there are repos (when the securities dealer has promised to deliver securities) and reverse repos (when the securities dealer has been promised securities). Starting first with repos, from our confidential data we know that over the July to August 2008 period the size of the tri-party repo and GCF Repo markets was about $\$ 2.5$ trillion. Our approach is to estimate the size of the total repo market and then back out the size of the bilateral repo segment. From the FR 2004 data, we know that, in July and August 2008, primary dealers had an average of $\$ 4.0$ trillion of repos outstanding, secured by open-marketeligible collateral (such as U.S. Treasuries and agency MBS; see the Federal Reserve Bank of New York Open Market Operations website for more details) 24 In the tri-party repo market, these types of collateral made up $83 \%$ of all collateral posted in July and August 2008. We assume that the distribution of collateral posted in tri-party repo also holds for the total repo market, so we inflate the FR 2004 number by 1.2. We also know that primary dealers made up $79 \%$ of all dealer activity on the tri-party repo market in July and August 2008. We assume that this percentage also holds in the total repo market, so we inflate the FR 2004 number by 1.266. From these calculations, our estimate of the total repo market is $\$ 6.1$ trillion. We then deduce that the bilateral repo size is $\$ 3.6$ trillion (see the left half of Table AI).

We repeat this exercise to estimate the size of the reverse repo market. Securities dealers do not conduct reverse repos on the tri-party repo market. From our confidential data, we know

\footnotetext{
${ }^{24}$ The FR 2004 data are collected from primary dealers and published by the Federal Reserve. These reports collect information on market activity from primary dealers in U.S. government securities. For more information, look up form "FR 2004" at http://www.federalreserve.gov/apps/reportforms/default.aspx.
} 


\section{Table AI \\ Size of the Bilateral Market in July and August of 2008}

This table presents estimates of the size of the bilateral repo and reverse repo markets. Note that it is not appropriate to add the total repo and reverse repo numbers to measure the size of the entire market because of double-counting. Every repo in the interdealer market is also a reverse repo, and we do not know the size of the bilateral interdealer market.

\begin{tabular}{lclc}
\hline Repo market segments & $\begin{array}{c}\text { Repo } \\
\text { (\$ billions) }\end{array}$ & Repo market segments & $\begin{array}{c}\text { Reverse Repo } \\
\text { (\$ billions) }\end{array}$ \\
\hline Total & 6,100 & Total & 4,060 \\
Tri-party repo \& GCF & 2,500 & GCF & 340 \\
Bilateral & 3,600 & Bilateral & 3,720 \\
\hline
\end{tabular}

that the size of the GCF reverse repo market was $\$ 340$ billion in July and August 2008. Once again using the FR 2004 data, we know that primary dealers conducted \$2.7 trillion of reverse repos. As described above, we multiply this number by 1.2 and 1.266, and estimate the size of the reverse repo market to be $\$ 4.1$ trillion. We then deduce that the size of the bilateral reverse repo market is $\$ 3.7$ trillion (see the right half of Table $\mathrm{AI}$ ).

\section{Appendix B. Timing of Events in the Tri-Party Repo Market}

This section describes the timing of events in the tri-party repo market. A particularly important step in the timing of a repo is the morning unwind, described below, which contributes to the fragility of this market. (More details on timing and institutional background can also be found in Copeland, Martin, and Walker (2010).) Given this paper's focus on the recent financial crisis, here we discuss market practice before the proposed reforms announced on May 17, 2010. For more information on the proposed reforms, see Federal Reserve Bank of New York (2010).

Morning: Trade Agreement

A cash investor and a collateral provider typically agree on a tri-party repo before 10 a.m. 
Conversations with market participants suggest that at least $90 \%$ of a dealer's tri-party repos are arranged before that time. The agreement specifies the amount of cash the investor will provide, the interest rate, the term of the repo (e.g., overnight or seven days), and the set of acceptable collateral. In contrast to the bilateral repo market, the margin that applies to a particular collateral class is not negotiated at the trade level but instead is specified in the appendix of the custodial agreement between the three parties. Hence, changing margins requires amending the agreement.

While little data are available, the majority of tri-party repos are reported to be overnight or "open" repos. Open repos roll over by default, unless one of the parties explicitly chooses to cancel the transaction. Krishnamurthy, Nagel, and Orlov (2012) show that, during the crisis, the term of $90 \%$ of the repos of money market mutual funds, by value, is one business day. A trade agreed to in the morning does not settle until the afternoon, around 6 p.m.

\section{Afternoon: Collateral Allocation}

Collateral providers know the composition of the portfolio of securities they need to finance in the afternoon, after the close of Fedwire ${ }^{\circledR}$ Securities Service, which settles government and agency securities, and the Depository Trust Company, which settles private securities. With this information, together with the information provided by the cash investor on the amount of financing they will provide and the securities they will accept as collateral, the dealers can allocate acceptable collateral to each trade. The clearing banks provide tools to make sure that only collateral acceptable to the investor gets allocated to repos and guarantee that the margin specified in the custodial agreement applies 25

The settlement of the initial leg of the repo trade occurs on the books of the clearing banks in the afternoon. Balances are transferred from the investor's to the collateral provider's balances account, while securities are transferred from the collateral provider's to the cash investor's securities account.

Next Morning: The "Unwind"

\footnotetext{
${ }^{25}$ Copeland et al. (2012) provide more details on this collateral allocation process.
} 
Between 8 and 8:30 the next morning, the clearing banks "unwind" all tri-party repo trades, including those that are not expiring. The unwind consists of sending the balances back to the investor's balances account and the securities back to the collateral provider's securities account on the books of the clearing bank. At the same time, the clearing banks extend intraday credit to the dealer since the securities are no longer financed by the tri-party investors.

The unwind gives collateral providers access to their securities during the day to satisfy delivery obligations. The clearing banks had not invested in systems that would allow intraday substitution of collateral in a repo so, without the unwind, dealers would not have had access to their posted collateral during the day 26 For the same reason, the unwind facilitates the process by which dealers optimally allocate their collateral for settlement at the end of the day, as described in Copeland et al. (2012).

The clearing banks employ a risk management concept called net free equity to ensure that the value assigned to the dealer's securities on their books exceeds the value of the intraday loan. Owing in part to how clearing banks manage their risk, dealers often keep securities that are not financed through tri-party repos in custody at the clearing bank. Hence, the net free equity concept and its influence on dealer behavior allow the clearing banks to provide intraday liquidity in an operationally efficient manner to dealers buying and selling securities.

Repos that have not expired are "rewound" every evening, at the same time as the initial leg of new repos is settled, but not necessarily with exactly the same collateral. Indeed, the collateral backing a repo can change over the life of the contract, as long as it remains in the set of eligible collateral, because tri-party repo is considered general collateral financing. Hence, the collateralization of a trade could vary from day to day or even intraday, as the dealer's portfolio of securities changes.

\footnotetext{
${ }^{26}$ Since the crisis, the clearing banks have introduced collateral substitution functionality, and the time of the unwind was moved to 3:30 p.m. on August 22, 2011.
} 


\section{Appendix C. Heterogeneity in Margins Across Dealers}

In this appendix we present evidence of the heterogeneity in margins across dealers. As mentioned in the paper, these results contrast with those in Krishnamurthy, Nagel, and Orlov (2012), who report little variation in margins using data on money market mutual funds and securities lenders. Our results are not necessarily inconsistent, however, because our data encompass a larger set of investors. We present these results to further document the way in which market participants use margins. 


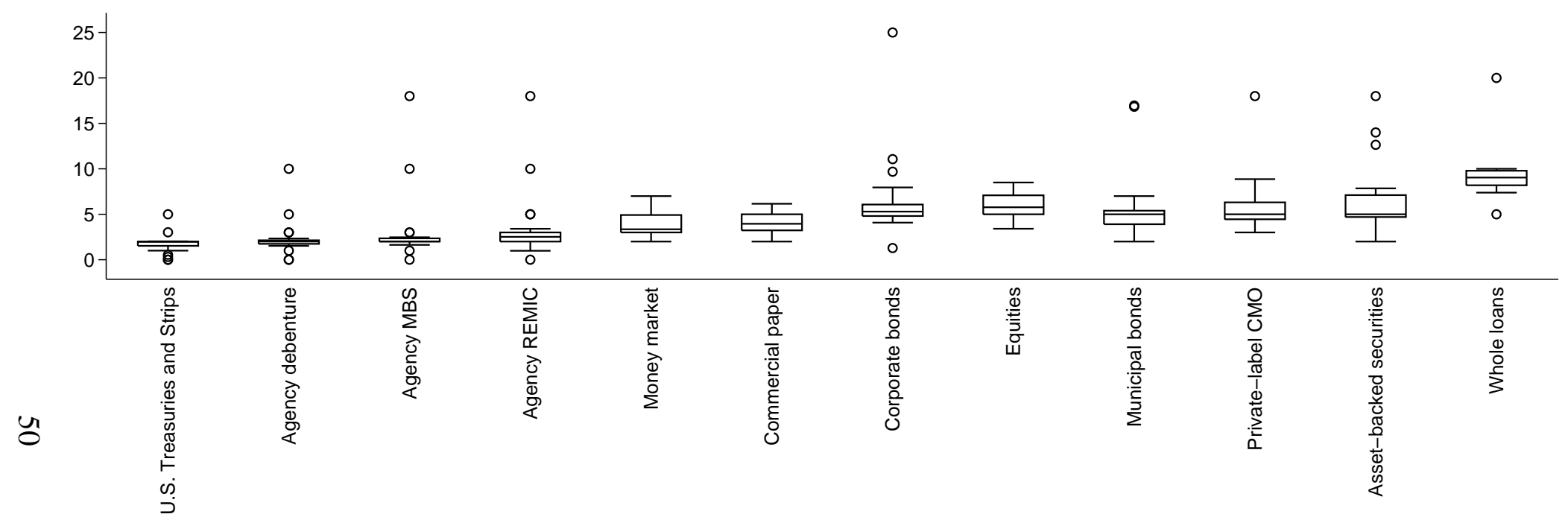

Figure C1. Distribution of tri-party repo margins by asset class. This figure presents the distribution of margins across dealers by asset class. Asset classes are ordered from left to right by quality, based on an ordering obtained from conversations with market participants. Margin is equal to the ratio of the value of collateral posted over the amount of cash lent minus one (reported as a percent). MBS is mortgage-backed securities, REMIC is real estate mortgage investment conduits, and CMO is collateralized mortgage obligations. Each box-and-whisker plots the distribution of median margins across dealers. The "box" portion comprises the 25th, 50th, and 75th percentiles of the distribution. The "whiskers" plot the upper and lower adjacent values, defined hereafter. Let $x$ define the variable of interest. Define $x_{i}$ as the $i$ th ordered value of $x$, so that $\left(x_{25}, x_{75}\right)$ represent the 25th and 75th percentiles, respectively. Let $U=x_{75}+\frac{3}{2}\left(x_{75}-x_{25}\right)$. The upper adjacent value is $x_{i}$ such that $x_{i}<=U$ and $x_{i+1}>U$. The lower adjacent value is defined similarly. The circles represent outliers: values of margins above and below the upper and lower adjacent values. Two margins associated with the same dealer (26 and 35 for private-label CMO and $\mathrm{ABS}$, respectively) are not shown. 
To illustrate the variance in margins across dealers, we plot the distribution of median margins for dealers by collateral class in Figure C1. For each collateral class, the box-andwhisker plot describes the distribution of median margins across dealers. The main feature of this figure is that dealers face substantial heterogeneity in margins, even for highly liquid assets such as U.S. Treasuries. While the average dealer faces a margin of $2 \%$ for U.S. Treasuries, some dealers negotiated margins of $1 \%$ or even $0 \%$. Further, one dealer is forced to pay a relatively high margin of 5\%. This same pattern is observed for most of the asset classes, particularly the lower-quality ones such as equity, ABS, and municipal bonds. While not apparent in Figure C1, dealers who face higher-than-average margins for one asset class often face higher-than-average margins for other asset classes. Further, it is typically the smaller dealers that face the higher margins. Consequently, while the use of collateral to secure loans can be thought of as a mechanism for minimizing counterparty risk, our research shows that differences among dealers are an important factor in the setting of margins.

The differences in margins across dealers are confirmed using regression analysis. Formally, letting $M A R G I N_{d j t}$ denote the average margin of dealer $d$ on collateral $j$ at time $t$, $D E A L E R_{d j t} \in\{1,2, \ldots, D\}$ denote the dealer's identity, and $C O L L T Y P E_{d j t} \in\{1,2, \ldots, J\}$ denote the collateral type, we estimate

$$
\operatorname{MARGIN}_{d j t}=\alpha_{0}+\sum_{k=2}^{D} I_{k=\operatorname{DEALER}_{d j t}} \eta_{k}+\sum_{k=2}^{J} I_{k=\operatorname{COLLTYPE}_{d j t}} \zeta_{k}+\alpha_{1} C_{d t}+\varepsilon_{d j t}
$$

where $I_{x=y}$ is an indicator variable equal to one when $x=y, C_{d t}$ is a dummy variable equal to one if dealer $d$ uses a specific clearing bank at time $t$, and $\varepsilon$ is an error term. The estimated parameters of the regression are reported in Table $\mathrm{C} 1$. To more easily compare the two sets of estimates, we rank the coefficient estimates for dealers and collateral class from smallest to largest. The omitted dealer has the lowest estimated fixed effect, while the omitted collateral type is U.S. Treasuries. The dealer coefficients range from 1.1 to 14.827 But the three largest

\footnotetext{
${ }^{27}$ The coefficients associated with dealers are all statistically significant at the 5\% level, except for dealer 3 , where the coefficient is statistically significant at the $10 \%$ level.
} 


\section{Table C1 \\ Coefficients on Margin Decomposition}

This table presents estimated coefficients that describe the differences in margins across dealers. The variable clrbnk is a dummy variable equal to one for trades settled by one of the clearing banks. The dealer with the lowest average margins and U.S. Treasuries and strips were the excluded dummies for dealer and asset classes, respectively. There are 85,256 observations and the $\mathrm{R}^{2}$ for the regression is 0.31 . Std Err is standard error, clustered by dealer-asset class pair. MBS is mortgage-backed securities, REMIC is real estate mortgage investment conduits, and $\mathrm{CMO}$ is collateralized mortgage obligations.

\begin{tabular}{lcclcc}
\hline Variable & \multicolumn{2}{c}{ Coefficient } & Variable & \multicolumn{2}{c}{ Coefficient } \\
\cline { 2 - 3 } & Estimate & Std Err & & Estimate & Std Err \\
\hline dealer 1 & 1.07 & 0.45 & Agency Debenture & 0.10 & 0.49 \\
dealer 2 & 1.32 & 0.68 & Agency MBS & 0.57 & 0.43 \\
dealer 3 & 1.34 & 0.81 & Agency REMIC & 1.09 & 0.48 \\
dealer 4 & 1.35 & 0.68 & Money Market & 2.16 & 0.47 \\
dealer 5 & 1.40 & 0.34 & Other & 2.18 & 0.86 \\
dealer 6 & 1.44 & 0.41 & Commercial Paper & 2.44 & 0.45 \\
dealer 7 & 1.45 & 0.69 & Municipal Bonds & 3.82 & 0.54 \\
dealer 8 & 1.48 & 0.41 & Corporate Bonds & 4.01 & 0.51 \\
dealer 9 & 1.50 & 0.36 & Equity & 4.38 & 0.70 \\
dealer 10 & 1.57 & 0.39 & Asset-Backed Securities & 4.99 & 1.02 \\
dealer 11 & 1.57 & 0.66 & Private-Label CMO & 5.37 & 1.40 \\
dealer 12 & 1.63 & 0.25 & Whole Loans & 6.85 & 0.78 \\
dealer 13 & 1.81 & 0.30 & & & \\
dealer 14 & 1.94 & 0.67 & & & \\
dealer 15 & 2.03 & 0.61 & & & \\
dealer 16 & 2.10 & 0.58 & & & \\
dealer 17 & 2.11 & 0.29 & constant & & \\
dealer 18 & 2.16 & 0.41 & clrbnk & & \\
dealer 19 & 2.30 & 0.32 & & & \\
dealer 20 & 2.46 & 0.51 & & & \\
dealer 21 & 2.78 & 0.60 & & & \\
dealer 22 & 2.83 & 0.71 & & & \\
dealer 23 & 2.84 & 0.59 & & & \\
dealer 24 & 2.84 & 0.54 & & & \\
dealer 25 & 2.89 & 0.65 & & & \\
dealer 26 & 3.03 & 0.91 & & & \\
dealer 27 & 3.78 & 1.36 & & & \\
dealer 28 & 3.83 & 0.76 & & & \\
dealer 29 & 9.04 & 1.95 & & & \\
dealer 30 & 9.87 & 4.02 & & & \\
dealer 31 & 14.77 & 2.43 & & & \\
\hline & & & & & \\
\hline
\end{tabular}


estimated coefficients look like outliers, and in fact these three are small dealers. Ignoring the three largest estimated coefficients, the coefficients on the dealer dummy variables range from 1.1 to 3.8. These coefficients imply that, holding fixed the collateral, dealers at the upper end of the range have to post more than two percentage points in collateral relative to dealers at the lower end.

The estimated coefficients on the collateral dummies range from 0.1 to 6.85 . These coefficients measure the average change in margin associated with posting different types of collateral, holding all else constant. The coefficients on the high-quality collateral of agency debenture and agency MBS are not statistically significant at the $10 \%$ level. Hence, holding fixed the dealer, we do not find a statistically significant difference in margins associated with a switch in collateral from U.S. Treasuries (the omitted asset class in the regression) to either of these collateral types. Except for agency debenture and agency MBS, the remaining estimated coefficients on collateral type are statistically significant at the 5\% level. For one of the lowest collateral types used in tri-party repo, for example, the estimated coefficient implies that, holding fixed the dealer, a switch from U.S. Treasuries to private-label CMO increases the amount of margin required by an average of 5.4 percentage points.

Given the existence of collateral, the importance of counterparty risk may seem surprising, but it has been highlighted by market participants. For example, "Craig Delany, a managing director at JPMorgan's Investment Bank ... stated that, in triparty repos, typically investors look to the counterparty (i.e., broker dealer) first and the collateral second when setting margins. In other words, a margin may not be sufficient for an investor if it has serious concerns about the viability of its counterparty" (Valukas (2010)). Further, Arora, Gandhi, and Longstaff (2012) find a similar result in their analysis of CDS. They estimate that prices of CDS were negatively impacted by the credit risk of the issuing dealer, despite these swaps being fully collateralized. 